\title{
Decapod crustacean grooming: Functional morphology, adaptive value, and phylogenetic significance
}

\author{
RAYMOND T.BAUER \\ Center for Crustacean Research, University of Southwestern Louisiana, USA
}

\section{ABSTRACT}

Grooming behavior is well developed in many decapod crustaceans. Antennular grooming hy the third maxillipedes is found throughout the Decapoda. Gill cleaning mechanisms are iquite variable: chelipede brushes, setiferous epipods, epipod-setobranch systems. However, microstructure of gill cleaning setae, which are equipped with digitate scale setules, is quite conservative. General body grooming, performed by serrate setal brushes on chelipedes and/or posterior pereiopods, is best developed in decapods at a natant grade of body morphology. Brachyuran crabs exhibit less body grooming and virtually no specialized body grooming structures. It is hypothesized that the fouling pressures for body grooming are more severe in natant than in reptant decapods. Epizoic fouling, particularly microbial fouling, and sediment fouling have been shown $\mathrm{r}$, $\mathrm{m}$ ans of amputation experiments to produce severe effects on olfactory hairs, gills, and i.ıcubated embryos within short time periods. Grooming has been strongly suggested as an important factor in the coevolution of a rhizocephalan parasite and its anomuran host. The behavioral organization of grooming is poorly studied; the na.ure of stimuli promoting grooming is not understood. Grooming characters may contribute to an understanding of certain aspects of decapod phylogeny. The occurrence of specialized antennal grooming brushes in the Stenopodidea, Caridea, and Dendrobranchiata is probably not due to convergence; alternative hypotheses are proposed to explain the distribution of this grooming character. Gill cleaning and general body grooming characters support a thalassinidean origin of the Anomura; the hypothesis of brachyuran monophyly is supported by the conservative and unique gill-cleaning method of the group.

\section{INTRODUCTION}

Many species of decapod crustaceans spend considerable time and energy in grooming or cleaning their bodies. A wide variety of specialized setal brushes and combs, located on the posterior maxillipedes and pereiopods, are used to brush, comb, scrape, and pick the other appendages, gills, and general body surfaces free of fouling organisms and debris. Decapods, like other crustaceans living in marine and freshwater environments, are under constant expısure to a wide variety of microbial and macroscopic fouling organisms. Space, in the 
form of a hard substrate, is often in short supply in aquatic environments. Clean surfaces immersed in marine and freshwater habitats are quickly colonized by microbial organisms, such as bacteria, unicellular algae, and fungi, and also by the spores and larvae of sessile plants and animals. The hard non-living exoskeleton of decapod and other crustaceans is a suitable substrate for the attachment of fouling organisms. In addition, the aquatic medium holds in suspension particulate debris, sediment, and detritus, which fouls the crustacean body. Fouling from whatever source can interfere with the normal sensory, respiratory, and locomotory activities of the crustacean. Crustaceans molt at periodic intervals and thus cast off the old exoskeleton with any debris or attached epizoites. However, the interval between molts can be lengthy in older individuals or in females incubating attached embryos. Serious microbial fouling can develop on olfactory setae, respiratory surfaces, and incubated embryos within a matter of days or weeks (Bauer 1975, 1977, 1978, 1979, Felgenhauer \& Schram 1978, Fisher 1983a, b). Consequently, diverse grooming structures and behaviors have evolved in decapod crustaceans in response to the selective pressure of fouling.

In the last ten years, a number of publications on decapod grooming have appeared (Bauer 1975, 1977, 1978, 1979, 1981, Felgenhauer \& Schram 1978, 1979, Martin \& Felgenhauer 1986). Holmquist $(1982,1985)$ has studied the morphology and behavior involved in body cleaning of amphipods; in this symposium volume, he discusses grooming adaptations in terrestrial crustaceans, including decapods. In another chapter, Pohle describes in detail gill grooming of lithodid crabs. Work on decapod grooming also has appeared in recent articles dealing with broader or other topics (e.g., Factor 1978, Ritchie \& Høeg 1981, Derby 1982, Schembri 1982a, b, Felgenhauer \& Abele 1983a, Fisher 1983a, b, Reese 1983, Bauer 1984). In an earlier paper (Bauer 1981), I surveyed grooming in the Decapoda. The purpose of the present report is to update and expand this review of decapod grooming, including more recent literature and new observations I have made on grooming in other decapod species. I will describe and discuss the following aspects of grooming in the Decapoda: functional morphology (limb structure, setal microstructure, limb movements), adaptive value, the relationship between grooming and parasitism, behavioral organization, and phylogenetic significance.

\section{METHODS}

To make figures of grooming behaviors, I photographed decapod species in laboratory aquaria using a camera with a 50-mm lens, extension tubes, and a flash with a $1 / 1500$-second duration. The resulting transparencies were projected onto a drawing surface; body posture and limb position during a grooming behavior were traced directly. For scanning electron microscopy (SEM), specimens were initially fixed in 10\% seawater formalin and later transferred to $70 \%$ ethanol for permanent storage. After dehydration through a series of washings with $95 \%$ and then $100 \%$ ethanol, specimens were sonically cleaned, critical-point dried with $\mathrm{CO}_{2}$, mounted on stubs, and gold coated for SEM observation and microphotography.

Reciprocal cleaning and other interactions among mouthparts (mandibles, maxillae, first and second maxillipedes) are excluded from the definition of grooming used here (see Introduction). The classification of the Decapoda by Bowman \& Abele (1982) will be followed. 


\section{GROOMING OF ANTENNULES, ANTENNAE, AND PEREIOPODS}

The most frequent and widely distributed grooming behavior of decapod crustaceans is antennular cleaning by the third maxillipedes (Zimmerman 1913, Roberts 1968, Snow 1973, Farmer 1974a, Bauer 1975, 1977, 1981, Wasserthal \& Seibt 1976, Fryer 1977, Felgenhauer \& Schram 1979, Schembri 1982a, b, Felgenhauer \& Abele 1983a, Martin \& Felgenhauer 1986). The outer (= lateral) antennular flagellum bears olfactory setae, the aesthetascs. In many decapods, such as the portunid crab Cronius tumidulus (Fig. 1A), the outer flagellum twists on its base so that the aesthetascs face forward. The antennular flagella are lowered between the distal segments of the third maxillipedal endopods, which grasp the antennule. The flagella are raised back to their original position as the endopods are lowered, and this action forces the flagella and their aesthetascs to be scraped and cleaned by the serrate setae
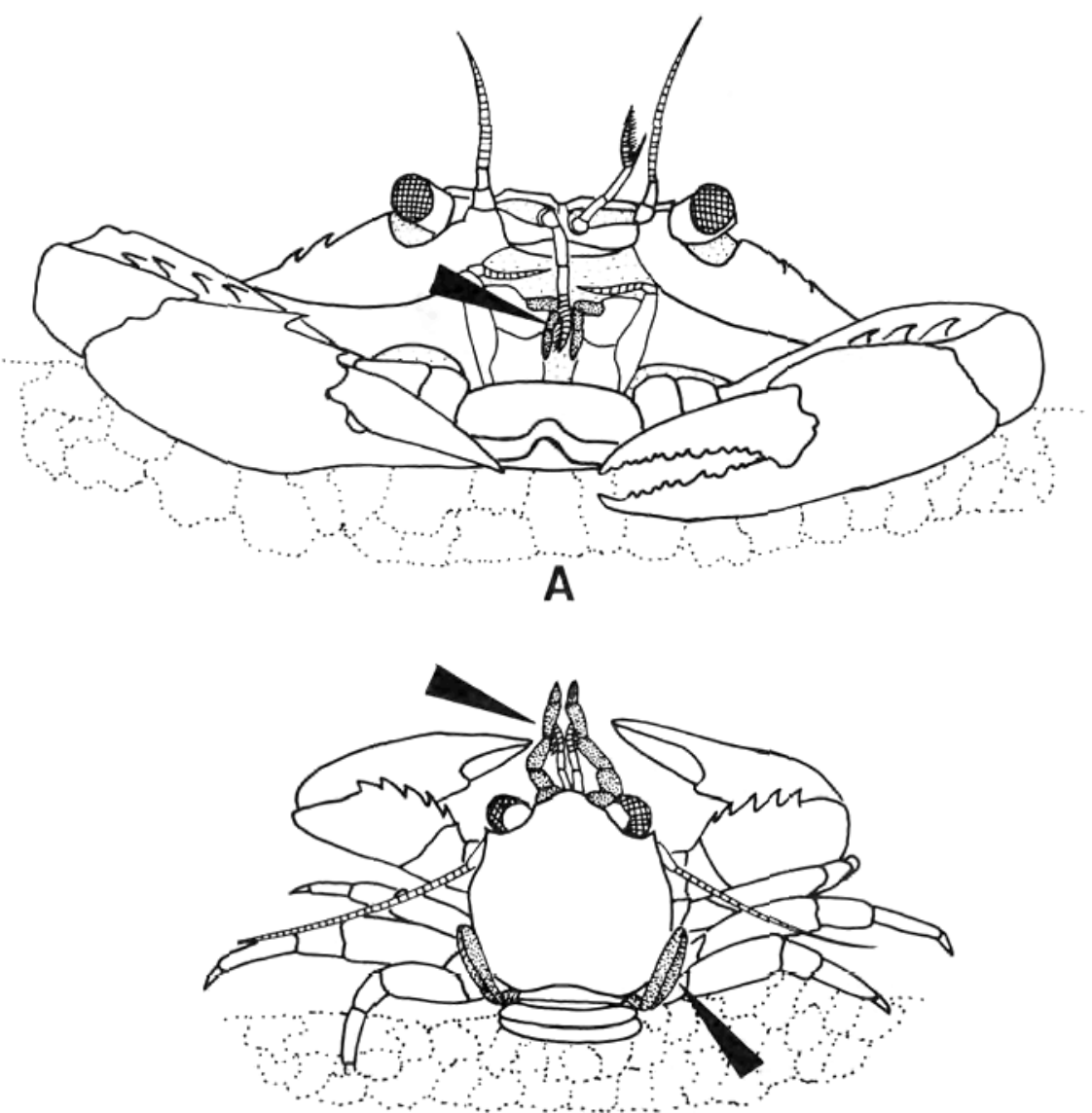

B

Figure 1. A. Antennular grooming in Cronius tumidulus; arrow points to palps (stippled) of third maxillipedes, which scrape lowered flagella of right antennule. B. Petrolisthes galathinus brushing both antennules (upper arrow) with third maxillipedes (stippled); lower arrow indicates fifth pereiopod (stippled), the gill and general body grooming appendage. 

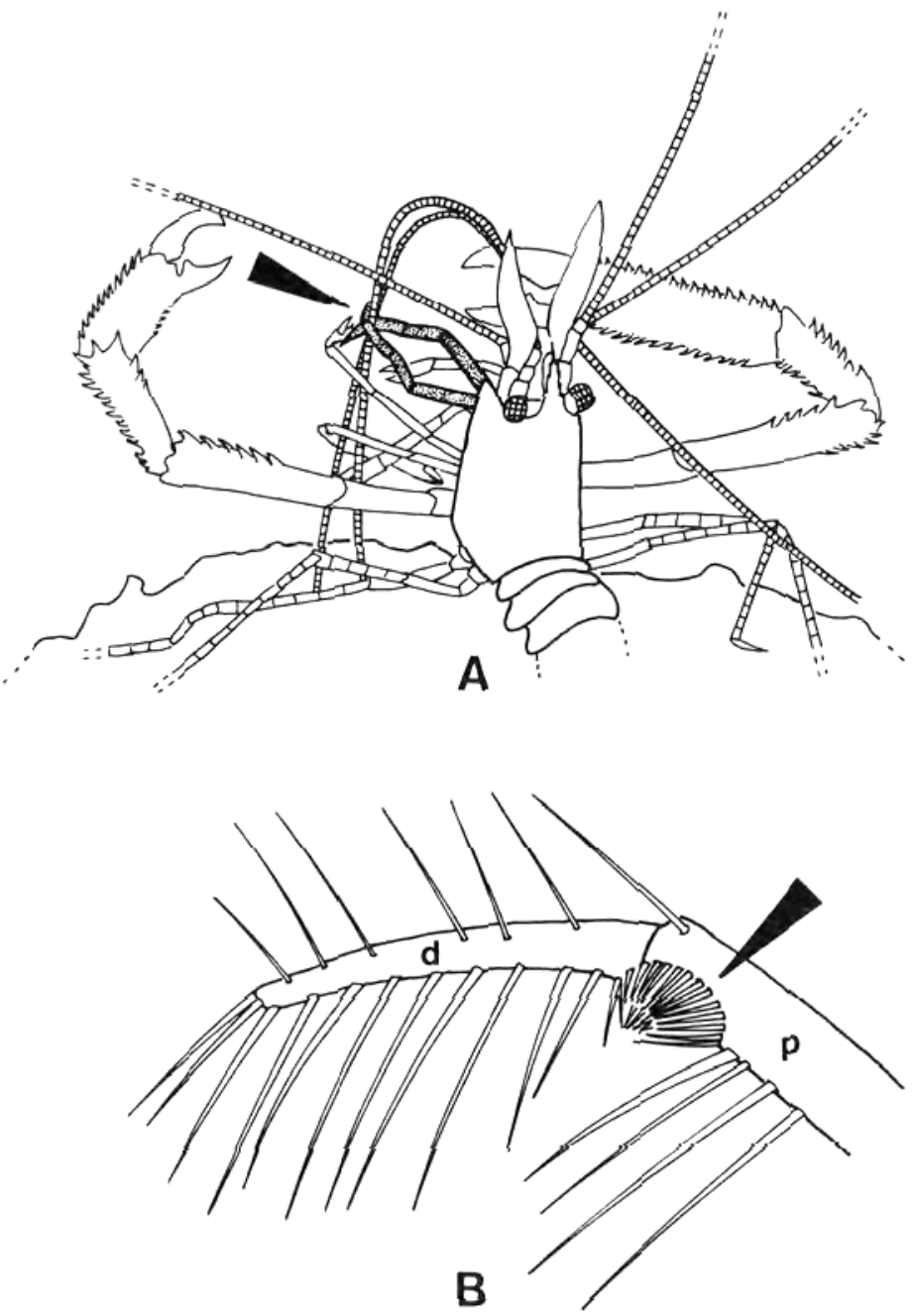

Figure 2. A. Grooming (arrow) of left antennular flagella by third maxillipedes (stippled), Stenopus hispidus. B. Medial view, distal end of S.hispidus third maxillipede; arrow denotes antennular grooming brush; d - dactylus, p propodus.

on the medial surfaces of the maxillipedal endopods. After a bout of antennular grooming, the third maxillipedes rub and scrape each other, ridding the setal combs and brushes of debris (autogrooming; Bauer 1975). The grooming setae are usually located on one or more of the distal segments (carpus, propodus, dactylus) of the third maxillipedes. The atyid shrimp Xiphocaris elongata (Fig. 4A-C) has an arrangement of grooming setae typical of carideans (Bauer 1977) in which the setae are set in rows along the rod-like endopod. In X.elongata, the comb rows are located on the proximal half of the fused propodus-dactylus, but in other carideans the setal rows may extend more distally and often occur on the carpal segment as well. In the crab C.tumidulus, there are two brushes (Fig. 4D, E) on the distal end of the carpus that, along with setae on the proximal half of the propodus, groom the antennules. Antennular 
grooming is somewhat different from the typical decapod pattern in the anomuran crab Petrolisthes galathinus (Fig. 1B) in that both outstretched antennules are cleaned with repeated scrubbing movements (with the third maxillipede carpal brush, Figs. 5D, E). Antennules are also groomed in the more typical fashion, i.e., lowered one at a time, except it is the second, not the third, maxillipedes that grasp and scrape them. Involvement of the second maxillipedes in antennular grooming has also been noted in Atya innocous by Felgenhauer \& Abele (1983a). Stenopus hispidus grooms the very long antennular flagella (Fig. 2A) with a cup-shaped setal brush located at the distal end of the third maxillipede propodus (Fig. 2B). It appears that, because the shrimp cleans only one antennule at a time, each flagellum fits neatly into the concavity of the setal brush of either the left or right third maxillipede. The tips of the antennular flagella are sometimes grasped and vigorously rubbed by the second maxillipedes. One exception to third-maxillipede grooming of antennules has been reported by Efford (1971) for the sand crab Emerita analoga. In this species, a specialized group of setae on the antennae groom the antennules.

The third maxillipedes groom the distal ends of the pereiopods in many decapods (see, e.g., Bauer 1975, 1977, 1981, Felgenhauer \& Schram 1979, Schembri 1982a). The pereiopod is extended forward and then grasped and groomed by the grooming limbs. Stenopus hispidus grooms the tips of the pereiopods with the second maxillipedes (pers. obs.).

Setal microstructure of the third maxillipede combs and brushes is similar throughout the Decapoda. Setae are typically serrate (type D setae of Factor 1978), i.e., with a double row of tooth setules that may or may not have other setulation. One generalization that needs further confirmation is that setae that groom antennular flagella, with their delicate olfactory setae, tend to have a finer, more complex setulation than more distal setae on the third maxillipede, which are involved in grooming less delicate pereiopod surfaces (Bauer 1975, 1977). An example of an antennular grooming seta with complex setulation is shown in Fig. 4C for Xiphocaris elongata. There is a double row of tooth setules that are somewhat finely serrate; the back side of the setal shaft is covered with digitate scale setules. In Cronius tumidulus, setae on the carpal brushes and on the proximal end of the propodus (Fig. 4E, 5A) groom the antennules and have a complex setulation. Stout serrate setae (Fig. 5B) on the distal end of the propodus are less complex and are probably used in pereiopod grooming. Similarly, in Petrolisthes galathinus, the carpal brush setae that groom the antennules have finely serrate tooth setules (Fig. 5C-E), whereas setae from the propodal and dactylar brushes (Fig. 6A-D) are composed of typical serrate setae with simple tooth setules. However, the second maxillipede setae (Fig. 6E, F), which also groom the antennules in this anomuran, do not follow this generalization - they have stout simple tooth setules.

The long chemotactile antennal flagellum of most dendrobranchiate (peneoid and sergestoid), stenopodidean, and caridean shrimps is groomed by specialized brushes of setae on either side of the carpal-propodal joint of the first pereiopod (P1-CP antennal grooming brushes) (Bauer 1975, 1978, 1981, Felgenhauer \& Schram 1979). In all of these shrimp-like taxa, often grouped in the past as the Natantia, grooming of the antennal flagellum is similar (Fig. 3). The first pereiopod carpal-propodal joint is draped around the base of the flagellum; as the pereiopod slides down the flagellum, the latter forms a characteristic loop as it is pulled through the P1-CP brushes. Stenopus hispidus has a very long antennal flagellum, and the second chelipede (and sometimes the third: Fig. 3) helps to depress the flagellum. However, these latter chelipedes have no setal brushes that groom the flagellum. In various carideans observed, the third maxillipedes may also be involved in this grooming movement (Bauer 1975, 1978). 


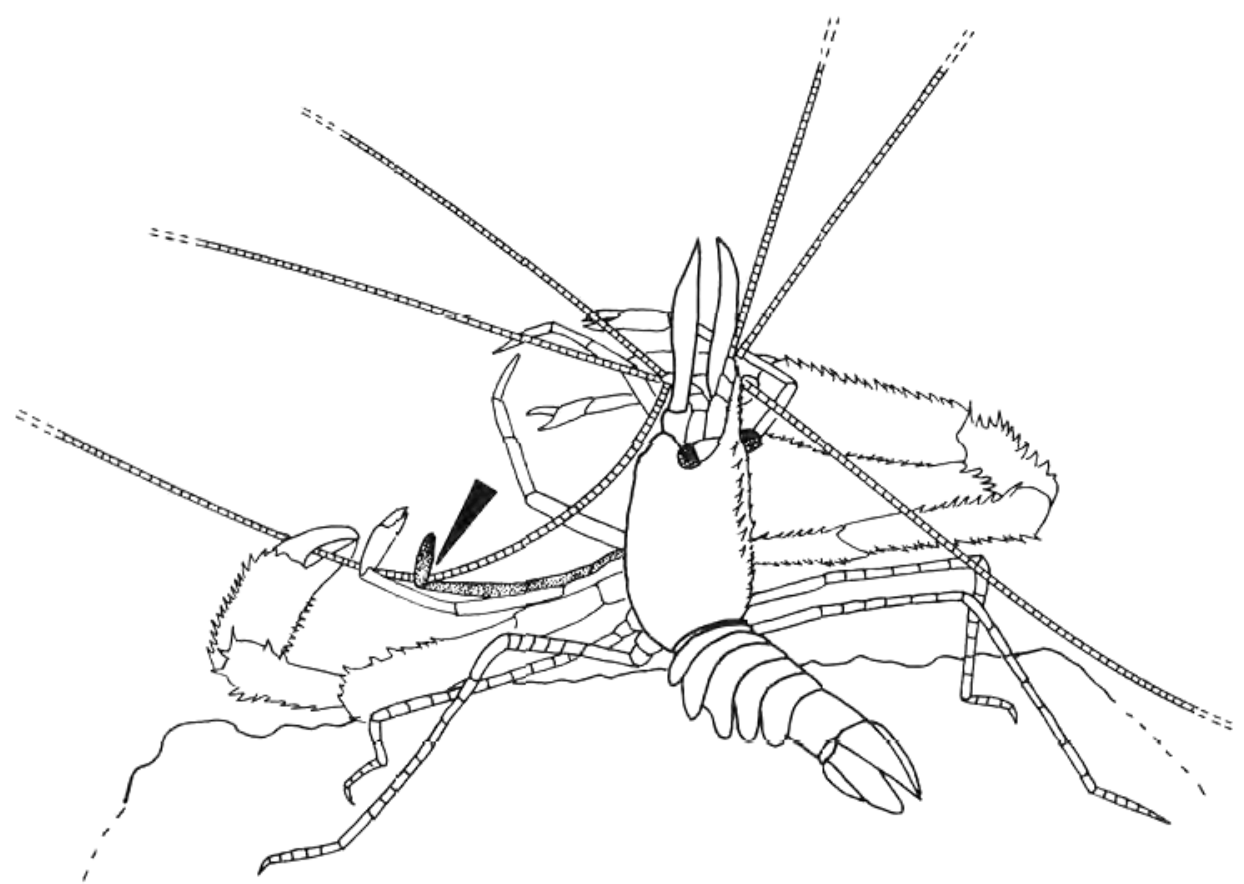

Figure 3. Grooming of second antennal flagellum by P1-CP grooming brushes, Stenopus hispidus; note (arrow) how antennal flagellum caught by carpal-propodal joint of first chelipede (pereiopod 1, stippled); flagellum being pulled through setal brushes located there (see Fig. 7A). In S.hispidus, second and occasionally third maxillipedes help to depress very long flagellum so that pereiopod 1 can groom it, as illustrated.

Although the morphology of the anterior pereiopods varies greatly among the decapod groups that have antennal flagellum grooming brushes, there is little variation in the location and form of these brushes: they always surround the carpal-propodal joint of pereiopod 1. To illustrate this point, P1-CP brushes and representative setae from them are shown for a stenopodid (Stenopus hispidus; Fig. 7A-F), a peneoid (Metapeneopsis martinella; Fig. 8A-C), and a caridean (Leander tenuicornis; Fig. 8D-F). To illustrate the low variation in this character within the Caridea, a taxon with different pereiopod 1 morphologies, the P1-CP brushes and setae are shown in the procaridid Procaris hawaiana (Fig. 9A-C); the hippolytid Heptacarpus pictus (Fig. 9D-F); another palaemonid, Palaemon ritteri (Fig. 10A-C), and the crangonid Crangon nigricauda (Fig. 10D-F). A common feature of the carpal brush (Figs. $7 \mathrm{~B}, 8 \mathrm{~B}, \mathrm{D}, 9 \mathrm{~A}, \mathrm{~B}, \mathrm{D}, 10 \mathrm{~B}, \mathrm{D}, \mathrm{E})$ is some long curved setae that help to trap or enclose the antennal flagellum between the carpal and propodal brushes when the propodus is flexed toward the carpus. Although setae from both brushes are serrate (Figs. 7C, D, F, 8F, 9C, F), the propodal brush (Figs. 7E, 8C, E, 9A, B, D, 10C, F) is usually somewhat more setose and may be the principal scraping or rasping structure.

Antennal cleaning brushes do not occur on the first or any pereiopod of 'reptant' decapod species, and grooming of the antennal flagellum is done with the third maxillipedes (Bauer 1981, Schembri 1982a, Martin \& Felgenhauer 1986). Within the Caridea, two of 15 families surveyed (Bauer 1978) did not show the P1-CP brushes. In the Atyidae, grooming of the antennal flagella is done with the third maxillipedes (Xiphocaris elongata, Fryer 1977; Atya 
innocous, Felgenhauer \& Abele 1983a); this is also true in the Alpheidae (Bauer 1979). In the dendrobranchiate genus Sicyonia, the P1-CP brushes are present in males but absent in females. Burkenroad (1934) first noted this sexual dimorphism in the P1-CP brushes (his 'special setiferus organ') of Sicyonia. Bauer (1981) incorrectly reported that this grooming character was absent in the Sicyoniidae.

\section{GILL CLEANING}

One of the diagnostic features of the decapod Crustacea is the enclosure of gills inside the branchial chamber. The gills are protected from injury, and their confinement in a narrow, enclosed space allows water to be pumped rapidly by them via the scaphognathite, a process of the maxilla that extends posteriorly into the branchial chamber. The major disadvantage of this arrangement is that the highly branched gills tend to filter out particulate matter from the respiratory stream. In addition, the rapid respiratory flow favors the growth of microbial organisms and epizoites on the gill surfaces. As a result, a variety of mechanisms has evolved to keep the gills and branchial chamber clean. Decapod gill-cleaning mechanisms have been surveyed by Vuillemin (1967) and Bauer (1981) and studied in detail by Bauer (1979) in caridean shrimps. One generalization that can be made is that decapod crustaceans often reverse the respiratory flow to flush the gill chamber. In many decapods, the incurrent openings to the branchial chamber are guarded by filters of setae. Although this arrangement may help prevent larger particles from entering the gill chamber, the setal filter mesh cannot be too fine - respiratory flow would be blocked. The vast majority of decapods investigated have mechanisms for cleaning the gills. Compound setae on grooming chelae, coxal setiferous papillae (setobranchs), and thoracic epipods scrape over and clean the gills. Below, I describe these gill-cleaning mechanisms and their distribution in the Decapoda.

\subsection{Epipodal gill-cleaning mechanisms}

In many decapods, setiferous epipods on the maxillipedes and/or pereiopods extend up between the gills, and limb movements scrape and rub the compound epipod setae against the gill lamellae or filaments. In the peneoid shrimps Penaeus (Bauer 1981) and Sicyonia, forked epipods occur on the third maxillipedes and anterior pereiopods. Fig. 11A shows a pereiopodal epipod of Sicyonia parri lying between and over adjacent gills. The microstructure of the setae on the epipod forks (Fig. 11B) is typical of setae involved in gill cleaning. The distal end of the setal shaft is covered with digitate scale setules. Epipod setae lie among the gill filaments (Fig. 11C), and it is easy to visualize movements of the limb agitating the epipod and its setae so that the scale setules shown in Fig. 11C scrape the gill filament surface. In palinurid lobsters, the leaf-like epipods (Fig. 11D) fit between the gills, and the anterior and posterior epipod surfaces are covered with setae of complex morphology. Note also in Panulirus argus (Fig. 11D, E) that the posterior side of the central axis of the podobranch that accompanies the epipod is similarly equipped with compound setae. The setae on both structures are typical gill-cleaning setae. Although there is considerable variation in detail, the setae are naked proximally, often with a well-developed setal socket (Fig. 11F) for setal mobility. More distally, the setae are equipped with digitate scale setules (Fig. 12A). Toward the tip of the setae, scale setules are partially replaced with very fine pointed or knife-like scales (Fig. 12A), and this replacement is complete at the very distal end of the seta. Similar 
setose epipods are the apparent gill-cleaning mechanisms in nephropid lobsters such as Homarus americanus and Nephrops norvegicus (Bauer 1981).

In brachyuran crabs, the gills are brushed by the maxillipedal epipods (Walker 1974, Bauer 1981). The epipod of the first maxillipede lies above (lateral to) the gills, whereas the epipods of maxillipedes 2 and 3 are located beneath (medial to) them. When the maxillipedes move, their epipods sweep over the gill lamellae. In Fig. 12B-D, the third maxillipede epipod and setae of Cronius tumidulus are shown. The epipod is covered with long barbed setae that are quite distinct from other types of gill- cleaning setae in the Decapoda. Instead of bearing scale setules, the setal shaft bears distally a single row of recurved hook setules (Figs. 12C, D).

\subsection{Setobranchs and epipod-setobranch complexes}

Setobranchs are setiferous papillae on coxae of the third maxillipedes and pereiopods of many caridean shrimps, astacid and cambarid crayfish, and axiid decapods. Compound setae, usually equipped with digitate scale setules similar to those on epipodial gill-cleaning setae (e.g., Figs. 11B, C, 12A), extend up to and among gill lamellae and filaments. Movements of the appendages cause these setae to move among and against the gill surfaces. Although Calman (1909) believed that these setae filtered the respiratory current as it entered the gill chamber, Huxley (1880) was more correct in his observations on the crayfish Astacus fluviatus: (setobranch setae) 'no doubt, serve to prevent intrusion of parasites and other foreign matter into the branchial chamber .... it is obvious they must share in the movements of the basal joints of the legs; and that, when the crayfish walks, they must be more or less agitated in the branchial chamber.' Bauer (1981) has illustrated the setobranch and its setae on a pereiopod of the crayfish Procambarus clarkii and has surveyed the distribution of setobranchs in decapod groups. In the Caridea (including Procaris), setobranchs, when they occur, are always functionally linked with a hooked epipod unique to carideans. These epipod-setobranch complexes have been described and illustrated by Bauer (1979), who also surveyed their distribution among 15 caridean families. The epipod hook of one appendage fits around the bases of the setobranch setae on the appendage posterior to it. During limb movements, when the coxae of these two limbs move apart, the setobranch setae are drawn down over the gill lamellae. When the coxae move toward each other, the setobranch setae are guided back to the gills through the epipod hook. When the epipod hook is displaced from the setobranch, the setae of the latter lose their location with respect to the gills. Generally, the presence of epipod-setobranch complexes is conservative at the generic and family level in the Caridea.

\subsection{Chelipede brushing}

In several families of carideans and anomurans, gills are brushed by tufts of setae on chelate first, second, or fifth pereiopods (Bauer 1979, 1981, Felgenhauer \& Schram 1979, Ritchie \& Høeg 1981, Martin \& Felgenhauer 1986, Pohle, this volume). The chelipedes are inserted into the gill chamber and are agitated rapidly so that the setal tufts on the chelae brush against the gills and other surfaces in the gill chamber (illustrated for the caridean Palaemon ritteri, in Fig. 13). In the Caridea, one pair of chelipedes is generally used in body grooming, and these brush and clean the gills when epipod-setobranch complexes have been lost (Bauer 1979, 1981). The second chela of the hippolytid Thor manning $i$ is shown in Fig. 12E. Setae from the chela brushes (Fig. 12F) show the digitate scale setules characteristic of gill-cleaning setae 
from epipods or setobranchs of decapods. In the Anomura, the most posterior pereiopod is a chelate grooming appendage. Bauer (1981) has illustrated the fifth pereiopod of the galatheid Pleuroncodes planipes and described gill-cleaning behavior in this species. I have also observed gill grooming in various porcellanid crabs (e.g., Petrolisthes galathinus), and Ritchie \& Høeg (1981) discuss the importance of gill brushing in several Petrolisthes species. Martin \& Felgenhauer (1986) describe and discuss gill grooming in aeglid anomurans, and the reader is directed to a detailed description and discussion of this behavior in lithodid crabs by $\mathrm{G}$. Pohle (this volume). In Petrolisthes galathinus, the pereiopod 5 carpus and chela bear dense tufts of setae (Fig. 13A). The setae that cover the tips of chela fingers are not compound (Fig. 14B, C). However, long sickle-shaped serrate setae (Fig. 14D) are located more proximally on the chela. The chelate fifth pereiopod of anomurans is reduced in size and often carried inside the gill chamber. During gill brushing, the carapace is usually tilted up posteriorly, and pereiopod 5 chelae can be observed brushing and picking at the gills. As in carideans, the chela fingers of Petrolisthes galathinus open and shut rapidly during gill grooming, but Martin \& Felgenhauer (1986) observed that the dactylar finger of Aegla spp. is only slightly movable. Thalassinideans such as Callianassa and Upogebia brush the gills with the chelate and setose fifth pereiopod (MacGinitie, 1930, 1934, pers. obs.), but this appendage is not so reduced as in anomurans. In axiid thalassinideans, the last pereiopods are little reduced and do not seem capable of reaching into the tightly enclosed gill chamber (Bauer 1981).

Stenopodid shrimps brush the gills with both the first and second chelipedes, which are cleaning chelipedes. However, the microstructure of the setal tufts (Fig. 14E, F) is atypical in that the setae are quite smooth, without setules.

The active gill-cleaning mechanism of chelipede brushing usually does not occur together with a passive method such as setiferous epipods or setobranchs. Bauer (1979) has shown that the major type of gill-cleaning method is generally a characteristic at the family level in the Caridea. Similarly, in thalassinidean decapods, those species with setobranchs (axiids) do not brush the gills, and those that do (callianassids, upogebiids) lack setobranchs (Bauer 1981). Stenopodid and anomuran species in which chelipede brushing of gills has been observed lack setiferous epipods or setobranchs (Bauer 1981, Martin \& Felgenhauer 1986, Aegla spp.). One notable exception to the mutual exclusivity of active and passive gill-cleaning methods occurs in the caridean family Hippolytidae, in which chelipede brushing and epipodsetobranch complexes may co-occur in some genera (Bauer 1979). However, as Bauer (1984) has demonstrated in the hippolytid genus Heptacarpus, epipod-setobranch complexes are primitive and are being or have been replaced by chelipede brushing in various Heptacarpus species. Additionally, the branchiostegite fringe setae, through which the respiratory stream must first flow, occur in heptacarpid species in which setobranchs are still relatively highly developed, but this fringe is lost in species with highly developed chelipede brushing (Bauer 1984). To my knowledge, no decapod group has setiferous epipods and setobranchs together; i.e., in the absence of cheliped brushing, one or the other of the passive gill-cleaning methods is developed.

\subsection{Scaphognathite setae}

Felgenhauer \& Abele (1983a) have recently called attention to the fact that Atya innocous, a shrimp with well-developed epipod-setobranch complexes, has compound setae extending back over the gills from the posterior edge of the scaphognathite (gill bailer). These setae 
probably function as a gill-cleaning mechanism. These authors clearly demonstrate this function with a SEM micrograph of the scaphognathite setae: the setal shaft is surrounded by digitate scale setules identical to those described above for setobranch setae, epipodial gillcleaning setae, and caridean chelipede brush setae. When the scaphognathite beats, its posterior fringing setae are swept over the lateral surfaces of the gills. Bauer (1979) largely overlooked this mechanism in carideans, although it was noted in the crangonid Paracrangon echinata, which appeared to lack any other gill-cleaning mechanism. Multidenticulate scaphognathite setae may well be a widespread accessory gill-cleaning mechanism throughout the Caridea or other groups.

\section{GENERAL BODY GROOMING}

Many decapod species engage in intense bouts of grooming in which body surfaces are scraped, brushed, and picked clean by brushes of serrate and/or multidenticulate setae on the chelae and/or distal segments of the posterior pereiopods. I have defined general body grooming (Bauer 1978, 1981) as all those preening activities exclusive of antennular, antennal, gill, and embryo cleaning. General body grooming includes such behaviors as scraping and brushing the carapace, eyes, and cephalic areas; pereiopod cleaning not performed by the third maxillipedes; and preening of abdominal parts, pleopods, and tail fan. Because decapods use the same appendages in general body grooming as they do to brush and clean incubated embryos, embryo cleaning can be thought of as a variation of general body grooming. I will include it in this section, but I will discuss it separately from general body grooming perse.

\subsection{Functional morphology of general body grooming}

The anterior chelipedes of many decapods are used in general body grooming. Specializations of chelipedes for grooming have been described in detail for several caridean shrimps by

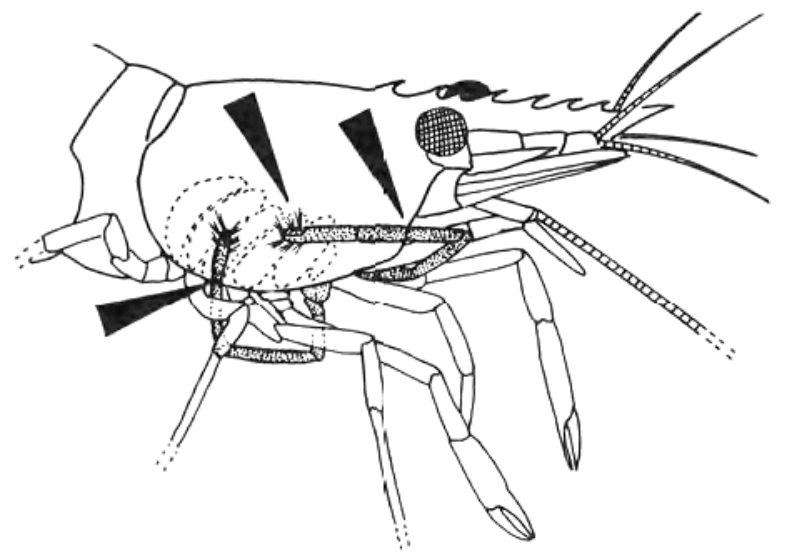

Figure 15. Chelipede brushing of gills in Palaemon ritteri (from Bauer 1979). Right and left arrows denote points at which cleaning chelipedes (stippled) inserted into right branchial chamber; center arrow indicates gill grooming by left chela; gills figured by dotted lines. 
Bauer $(1975,1978)$ and in the caridean Palaemonetes kadiakensis by Felgenhauer \& Schram (1979). One pair of chelipedes is partially specialized as cleaning appendages. The cleaning chelipede is the more slender of the two pairs of chelipedes typical of carideans, and the chela bears tufts of setae used in brushing the body. Bauer (1978) found that these setae are multidenticulate in groups that also brush the gills but were more or less simple in their microstructure in species that used them solely for general body grooming. Whenever the grooming chelipede is the second chelipede, the carpus is subdivided into few to many segments, increasing greatly the flexibility of the limb in grooming (Bauer 1978; Fig. 16B). Chelipede preening is illustrated for the atyid Xiphocaris clongata and the hippolytid Heptacarpus paludicola (Fig. 16A, B). Chelipedes are brushed rapidly over surfaces, and chela fingers pick and tug at the exoskeleton, especially in areas of articulation between body or limb segments. In grooming the abdomen, shrimps often assume characteristic postures (Fig. 16B) in order to reach posterior abdominal segments or appendages. Stenopodid shrimps use both the setose first (Fig. 13E) and second chelipedes for body preening (Bauer 1981, Reese 1983). Very little has been reported on chelipede grooming in peneoids. Bauer (1981) observed all three pairs of chelae grooming the body of the aristeid Gennadas sp. and believed it likely, on the basis of morphology, that chelipede grooming is widespread in this group.

The generally heavier and less mobile chelipedes of other decapods can groom the body (Bauer 1981), although the intensive rapid brushing characteristic of carideans and stenopodids is not frequently reported. Crayfishes such as Procambarus clarkii (Bauer 1981) and Austropotamobius pallipes (Thomas 1970) and nephropid lobsters (Farmer 1974a) pick at the body with the minor (second and third) chelipedes. Chelipede grooming by brachyurans is rarely reported (Bauer 1981), and the heavy chelate first pereiopod of these crabs seems poorly adapted for grooming. One exception I have observed is the majid crab Stenorhynchus seticornis, which often grooms the body with its slender chelipedes. (See also the chapter on grooming in terrestrial decapods by Holmquist, this volume.)

The fifth pereiopod is modified as a grooming limb in many decapods. The chelate fifth pereiopods of anomurans (Fig. 13A) are the only decapod appendages used exclusively for grooming. In the galatheid Pleuroncodes planipes and in Petrolisthes spp., this grooming limb can reach and clean most areas of the body. Martin \& Felgenhauer (1986) have reported and illustrated, however, that the fifth pereiopod cannot reach anterior portions of the cephalothorax in aeglid crabs. Members of several caridean families use pereiopod 5 for grooming the abdomen and posterior parts of the cephalothorax (Fig. 16B, C) (Bauer 1975, 1978, Felgenhauer \& Schram 1979). In atyid shrimps, the dactylus of the fifth pereiopod is modified into a comb of serrate setae. The atyid dactylar comb, unique among carideans, is shown for Xiphocaris elongata (Fig. 14A-C) (see Felgenhauer \& Abele 1983a for Atya innocous, Fryer 1960, 1977 for other atyids). In X.elongata, the dactylar comb is composed of a single row of serrate setae that are somewhat atypical of serrate setae of grooming brushes and combs. Instead of the usual double row of tooth setules of similar size, there is a row of large tooth setules on one side of the setal shaft accompanied by another row of very smal] numerous tooth setules (Fig. 14B, C). Much more typical caridean pereiopod 5 grooming brushes are those of Palaemon ritteri and the alpheid Betaeus macginitieae (Fig. 14D-G). Setal combs and brushes on the distolateral surface of the propodus are composed of typical serrate setae that may (Fig. 14G) or may not (Fig. 14E) have scale setules. Similar grooming setae are found on the propodus of the fourth and/or fifth pereiopod in axiid thalassinideans, astacid and cambarid crayfishes, and nephropid lobsters (Bauer 1981). Stenopodid and 
60 Raymond T.Bauer
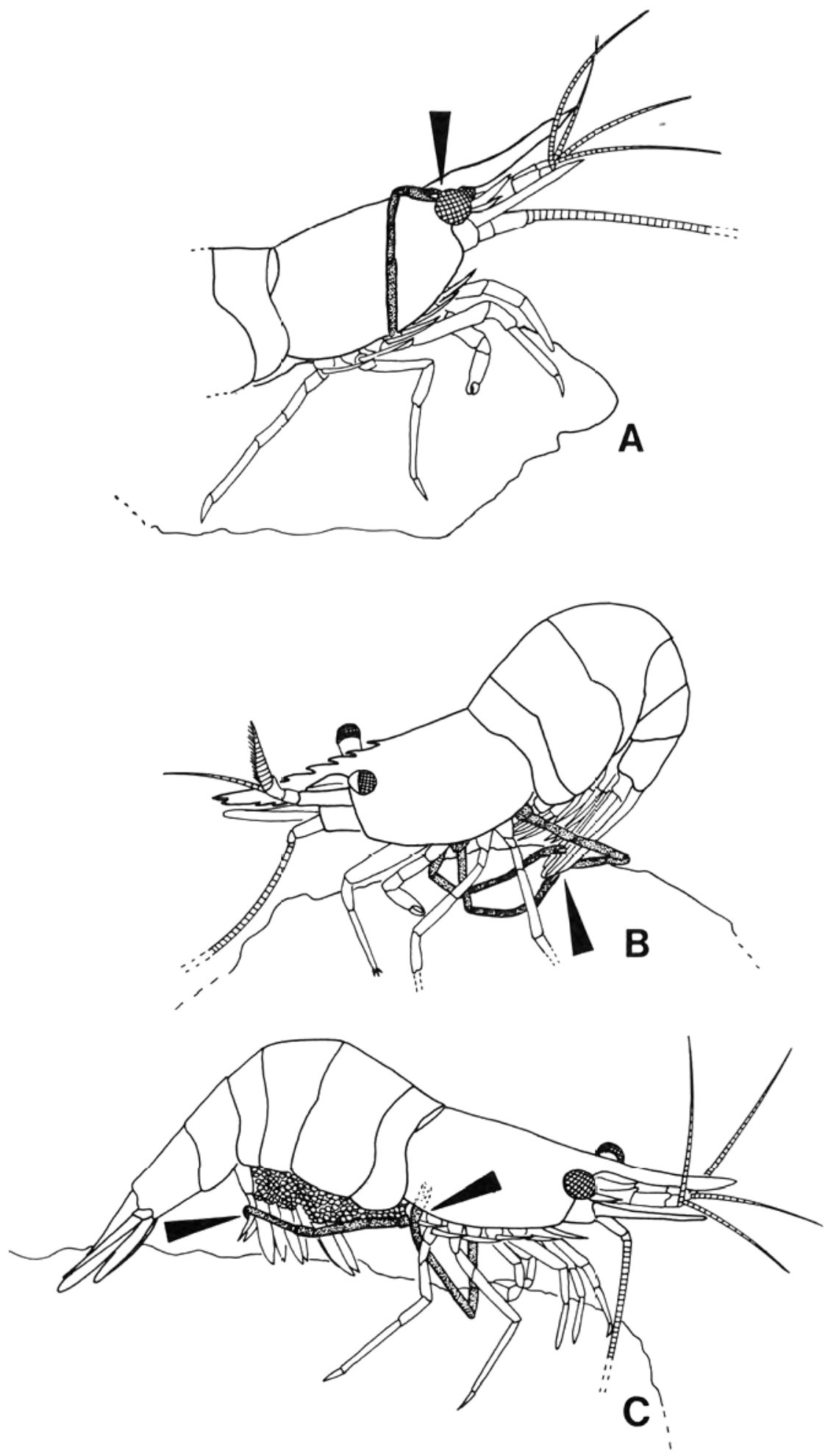
peneoid shrimps have no setal brushes or combs on the posterior pereiopods. No brachyuran pereiopod 5 grooming structure has been described. Bauer (1981) reported that portunid crabs may use the fifth pereiopod, unmodified for grooming, to sweep over the carapace. I have observed Stenorhynchus seticornis using the pointed pereiopod 5 dactylus to pick and probe at the body.

\subsection{Embryo cleaning}

Female pleocyemate decapods carry developing embryos attached to the pleopods under the abdomen. During incubation, many decapods brush and clean the embryos with the appendages used in general body grooming. Embryo grooming is commonly reported in caridean shrimps (e.g., Bauer 1979, Fryer 1960, 1977, Fisher 1983a, b) and anomuran crabs (e.g., Ritchie \& Høeg 1981, Martin \& Felgenhauer 1986, pers. obs. on galatheids, porcellanids). Other decapods that groom the body with chelipedes or pereiopod 5 brushes groom incubated embryos, e.g. Callianassa californiensis (see MacGinitie 1934), Nephrops norvegicus (see Farmer 1974b), Austropotamobius pallipes (see Thomas 1970), Panulirus spp. (with chelate pereiopod 5 dactylus; Phillips et al. 1980). Reports on embryo cleaning in brachyuran crabs are conspicuously absent from the literature. Hiatt (1948) observed attempts by Pachygrapsus crassipes to remove foreign matter from its clutch of embryos; the large chelae rather clumsily destroyed a number of the embryos.

\section{ADAPTIVE VALUE OF GROOMING BEHAVIOR}

Experimental work on the adaptive value of cleaning behavior has taken the form of amputation experiments. A grooming appendage is removed from an experimental animal; in controls a similar amputation is performed on some other appendage not involved in grooming. Both controls and experimentals are set out in cages to expose them to potential fouling from particulate debris and the settling stages of epizoites or parasites. Experiments of this type have been very successful in demonstrating the environmental pressures responsible for the evolution of grooming behavior in decapod crustaceans. Amputation experiments have been mainly limited thus far to caridean shrimps (Bauer 1975, 1977, 1978, 1979, Felgenhauer \& Schram 1978, Fisher 1983a, b) and porcellanid crabs (Ritchie \& Høeg 1981). However, the results of these experiments, in addition to observations on epizoic fouling related to grooming behavior in decapods, allow one to draw some conclusions and to make hypotheses on the adaptive significance of grooming.

\subsection{Antennular grooming}

The outer flagellum of the antennule carries the olfactory setae, or aesthetascs, which have been demonstrated in decapod crustaceans to be major sites of chemically mediated percep-

Figure 16. A. Chelipede 2 (stippled) scraping eye (arrow) of Xiphocaris elongata. B. Grooming of tail fan (arrow) by cleaning chelipedes (stippled) and left fifth pereiopod (stippled) in Heptacarpus paludicola. Cleaning chelae picking and scraping ventral and posterior edges of tail fan; propodal brush of pereiopod 5 grooming dorsal side of tail fan. C. General body grooming in Xiphocaris elongata. Anteriorly (arrow) second chelipede (stippled) cleaning ventral edge of branchiostegite. Note chela partially inserted into branchial chamber; however, there is no chelipede gill brushing in this species (epipod-setobranchs, scaphognathite setae probable gill-cleaning setae). Posterior arrow shows pereiopod 5 dactylus, equipped with setal comb (see Fig. 14A), grooming fifth pleopod. 
tion of food and mates at a distance (see references in Reese 1983, Snow 1973). Antennules are flicked or rapidly rotated in order to circulate water through the aesthetascs (Snow 1973, Bauer 1975, 1977, 1981). This water flow, which brings potential chemical stimuli into contact with aesthetascs, also carries particulate debris that can cover and foul olfactory surfaces. It creates favorable conditions for the growth of bacteria, unicellular algae such as diatoms, and other epizoic organisms, as has been clearly demonstrated with amputation experiments in hermit crabs (Snow 1973) and the caridean shrimps Heptacarpus pictus, Pandalus danae (Bauer 1975, 1977), and Palaemonetes kadiakensis (Felgenhauer \& Schram 1978). Within days of amputation of the antennular grooming appendages (third maxillipedes), the antennules began to darken because of the accumulation of debris but especially because of the growth of diatoms, the long-chained bacterium Leucothrix, and other epizoites on the aesthetascs. Aesthetascs of control shrimps with third maxillipedes intact remained clean. In H.pictus experimentals, actual damage was done to the aesthetascs. Within two weeks of third maxillipede amputation, all aesthetascs were broken off at their bases. Bauer (1977) hypothesized that this damage occurred in H.pictus because the antennule is spun rapidly to promote water circulation; extra drag of epizoites on possibly structurally weakened aesthetascs may have caused the breakage. Interruption of distance chemoreception by fouling is the probable selective pressure that has led to frequent antennular grooming by the third maxillipedes throughout the Decapoda. However, tests for loss of chemoreceptive ability in experimentally fouled animals should be conducted to support this hypothesis.

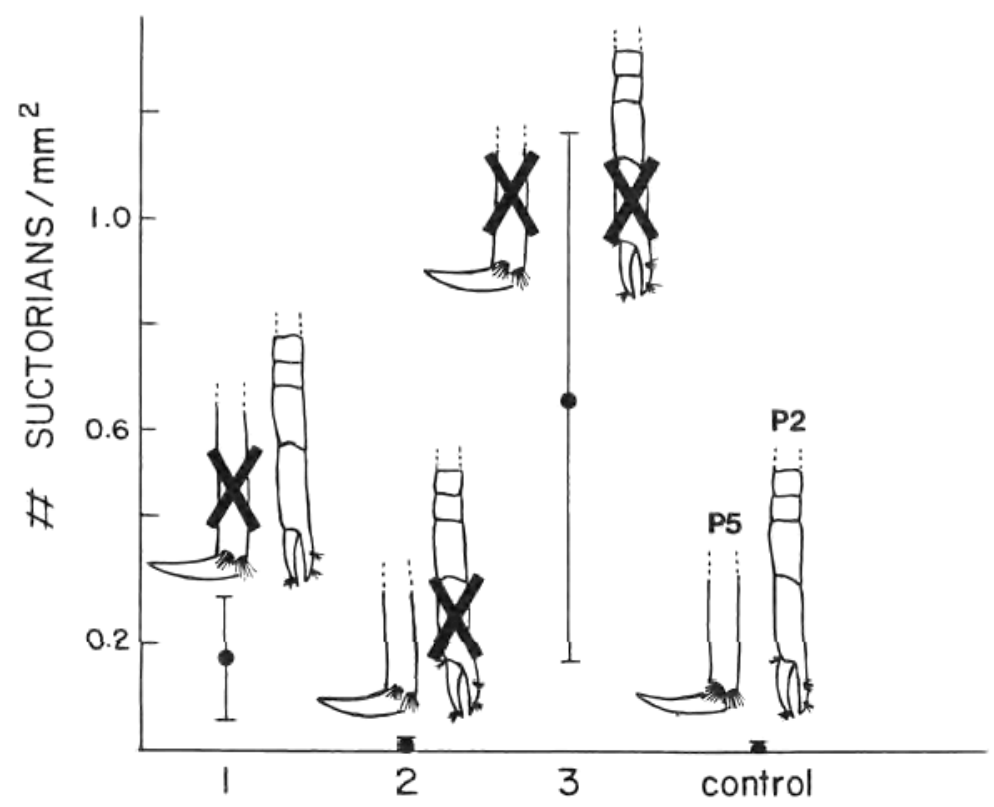

TRE ATMENT

Figure 17. Results of an amputation experiment on Pandalus danae. Density (mean, 95\% confidence limits) of epizoic suctorians on uropod illustrated in four treatments. Behavioral observations indicated that uropod (and rest of abdomen) groomed by fifth pereiopods (P5) while cephalic areas groomed by second chelipede (P2). The 'X's' indicate which pairs of grooming limbs (P2, P5, or both) amputated in group of $P$.danae. In controls, nongrooming appendage (pereiopod 3) amputated. See Bauer (1975) for details. 


\subsection{Gill cleaning}

The enclosed multibranched gills of decapods that experience a constant rapid flow of water are a prime candidate for fouling. Bauer (1979) amputated the gill brushing chelipedes of Heptacarpus pictus and Palaemon ritteri and exposed them, with controls (pereiopod 3 removed), to environmental fouling. Epizoic fouling similar to that described above on antennules occurred on gill lamellae of experimentals but not of controls. Sediment fouling, measured by comparison of optical density of gills, was significantly higher on experimental gills. Within a week of chelipede amputation the gills of experimentals were noticeably darkened and visible through the carapace, whereas those of controls remained clean. Experimental shrimps suffered a high mortality when exposed to oxygen stress; control shrimps did not. Ritchie (pers. comm.) noted high sediment fouling of gills in Petrolisthes cabrilloi when this porcellanid's grooming limb was removed. (See the experimental work on gill grooming in lithodid crabs in the chapter by G. Pohle, this volume.)

No experimental work has been done that actually demonstrates the effectiveness of other gill-cleaning mechanisms, i.e., setiferous epipods or setobranchs. Walker (1974) did show that gill areas of the brachyuran Callinectes sapidus swept by the maxillipedal epipod setae had lower infestations of gill barnacles. Amputation experiments to demonstrate the effectiveness (or lack of it) of epipodial setobranchs are needed.

\subsection{General body grooming}

Amputation experiments dealing with general body grooming have only been performed on caridean shrimps (Bauer 1975, 1978, Felgenhauer \& Schram 1978). Exposure of experimental and control shrimps varied from a few days (Felgenhauer \& Schram 1978, Palaemonetes kadiakensis), to two weeks (Bauer 1978, Heptacarpus pictus), to nearly a month (Bauer 1975, Pandalus danae). Sediment fouling appeared on experimental shrimps within a few days, whereas controls remained clean throughout the experiment. Particulate fouling occurred especially in areas of the body that were heavily setose or topographically complex, i.e., articular areas, grooves, crevices, etc. Epizoic fouling by bacteria, unicellular algae, stalked protozoans, and early settling stages of sessile invertebrates such as bryozoans and hydroids was observed on experimental but rarely on control shrimps. Fouling by epizoites was quantified as measurements of the density of an easily counted sessile protozoan on different parts of the body (Bauer 1975, 1978). An example is given in Fig. 17, composed from data on the general body grooming experiment on Pandalus danae (Bauer 1975). Behavioral observations indicated that the cleaning chelipedes groomed the anterior part of the cephalothorax but that the abdomen was groomed by the fifth pereiopod. Figure 17 shows the density (mean, 95\% confidence limits) of the suctorian Ephelota sp. on the right uropods of four groups of Pandalus danae in an amputation experiment. In treatments 1 and 3 (fifth pereiopods removed), suctorian fouling was significantly higher than in treatment 2 (only second pereiopods removed) or the control (pereiopods 3 removed) treatment. Thus, as hypothesized, an area groomed by the fifth pereiopod showed significantly higher epizoic fouling in shrimps prevented from grooming that area by amputation. The uropods of treatment 2 and control shrimps (pereiopod 5 present) showed very little fouling. (See Bauer 1975 for a more detailed analysis of this experiment.)

In all experiments, glass slides or asbestos board settling plates were exposed to fouling in 
the same cage with experimental and control shrimps. These settling plates showed the same epizoic fouling as was seen on experimental (non-grooming) shrimps (Bauer 1975, 1978, Felgenhauer \& Schram 1978). Thus, the exoskeleton of these crustaceans acts as an inanimate substrate for fouling organisms in the absence of grooming.

Within the Decapoda, the major morphological grades are the natant, macruran, and brachyuran body forms. This series of body types is correlated with locomotion. Natant decapods (dendrobranchiates, carideans, stenopodids) have a series of morphological adaptations for both efficient forward swimming and the retrograde escape response (see Bauer 1981, based on Calman 1909, Glaessner 1960). At the other extreme, brachyurans have lost swimming abilities (portunid swimming is secondarily derived) and the backward abdominal escape response; the brachyuran body is adapted for efficient walking and running. Macruran types (astacidean crayfishes and lobsters, palinuran lobsters, axiid and other thalassinideans) are intermediate in body form. Correlated with this morphological-locomotory trend within the Decapoda is the degree of general body grooming specialization (Fig. 18). General body grooming adaptations, e.g.. grooming chelipedes and pereiopod 5 brushes and combs, are best developed in natant types such as carideans and stenopodids. Reports of intensive,

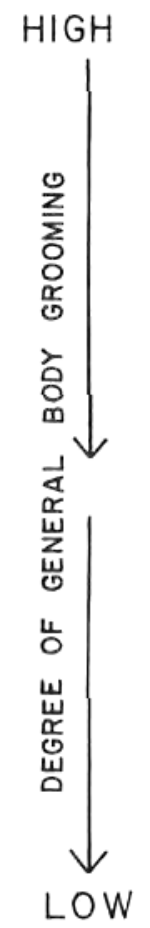

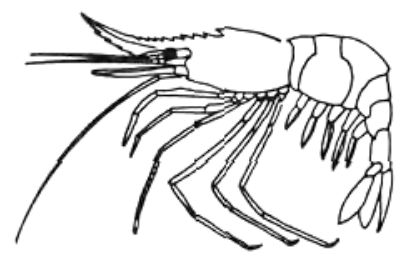

natant
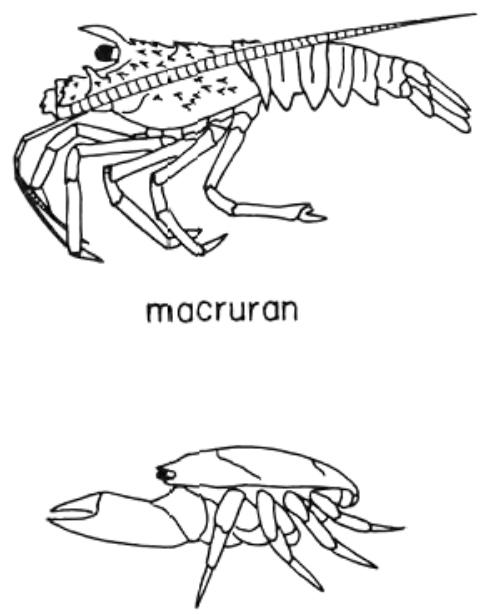

brachyuran

\section{SWIMMING}

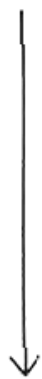

CRAWLING

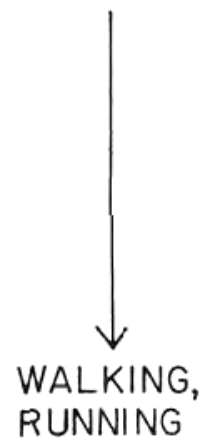

RUNNING

Figure 18. Relationship between morphological grade, locomotion, and degree of specialization of general body grooming in Decapoda. See discussion in section 6.3. 
prolonged bouts of general body grooming cited throughout this review are usually on natant species. As noted above, morphological adaptations for general body grooming are unknown in the Brachyura, and there are few reports of general body cleaning in this group (see chapter by Holmquist, this volume). Macruran types are intermediate between natants and brachyuran crabs. A major exception occurs in the Anomura, in which groups of various morphology: including the brachyurous porcellanids, often have well developed general body grooming (chelate pereiopod 5).

The relationship between general body grooming and trends in decapod morphology described above suggest hypotheses about the adaptive value of general body grooming. As Bauer (1981) has pointed out, reports of macroscopic body fouling are rare in natant-like decapods but relatively common in reptant decapods such as palinurid or nephropid lobsters and brachyuran crabs (e.g., Kaestner 1970, Warner 1977, Stewart 1980). Bauer (1978, 1981) has discussed how even light epizoic fouling might interfere with swimming in natant decapods. Epizoites projecting out from the morphologically streamlined body of a natant could produce a drag much as fouling organisms on a ship's hull reduce the efficiency of movement through the water. Decapods that depend less on swimming or that do not swim are not subjected to this evolutionary pressure, and general body grooming is not so intensive or morphologically specialized as in natant shrimps. Other aspects of epizoic fouling on the body would seem to be disadvantageous to all decapods: fouling in articular areas between body and limb segments that blocks movement, coverage or blockage of the many types of sensory sensilla occurring over the decapod cuticle. It is probably for the latter reason that general body grooming does occur to various degrees in macrurous decapods and brachyuran crabs, but it is simply less highly developed than in the natants. These are tentative generalizations that need to be supported by data on many more species throughout the Decapoda.

\subsection{Alternatives to general body grooming}

Many decapods that do not appear to engage in general body grooming remain quite clean. Although macroscopic fouling is certainly more common in brachyuran crabs, many species can be encountered that are free from fouling. Molting in crustaceans certainly rids the body of all fouling. Warner (1977) considered molting to have value as a 'spring cleaning' in older brachyuran crabs suffering from heavy epizoic fouling and clogging of limb articulations with sand. That high molting rates might have evolved for the primary purpose of cleaning seems improbable, given the metabolic expense and high mortality risks associated with ecdysis. Bauer (1981) has hypothesized that decapods burrowing directly into sediments are under lower epizoic fouling pressures, as these conditions are unfavorable for epizoic growth. Semiterrestrial and terrestrial decapods are certainly under little or no danger of epizoic fouling, although other types of fouling may be important (see Holmquist, this volume). Glynn (1970) has shown experimentally how a sphaeromatid isopod (lacking general body grooming) suffers heavy algal fouling when exposed to light. However, the animal is nocturnal, normally hiding under shelters during the day, and thus it escapes algal fouling. The nocturnal behavior of non-grooming decapods might be explained (at least partially) by such an escape from light. Finally, it may be that some decapods have exoskeletons that discourage fouling either physically (surfaces difficult for larvae to settle on) or chemically (secretion of antifouling agents by the tegumental glands). 


\subsection{Embryo cleaning}

With the exception of dendrobranchiate shrimps, all decapod crustaceans incubate their embryos on the abdominal appendages for varying periods of time until the embryos hatch as advanced larvae. Female decapods either beat natatory pleopods or rapidly fan or flap the entire abdomen (as in anomuran and brachyuran crabs) to create a flow through the embryo mass in order to meet the respiratory needs of embryos and to carry away their waste products. This water circulation also introduces sediment and detrital particles, epizoic larvae, algal spores, and bacterial and fungal propagules into the embryo mass. Thus, the surface of embryos can serve as a substrate for epizoic fouling.

Embryo grooming has obviously evolved to maintain embryos free of this fouling. Bauer (1979) demonstrated with amputation experiments the consequences of a lack of embryo care in the carideans Heptacarpus pictus and Palaemon ritteri. The cleaning chelipedes of experimental females and the third pereiopods of control females, both carrying recently spawned embryos, were amputated. Within two weeks, extensive embryo death occurred in the embryo masses of experimental females, whereas no embryo mortality occurred in control females. In H.pictus, conservative measurements of embryo mortality ranged from 20 to $30 \%$. Experimental embryo masses were heavily fouled by sediment, and embryo surfaces were covered by bacterial and other epibiotic fouling. Fisher (1983a, b) conducted similar but more elegant experiments with Palaemon macrodactylus. Bacterial counts from embryos of experimental females and from embryos detached from females (ungroomed embryos) were much higher than those from females with grooming chelipedes (Fisher 1983a). SEM micrographs show how bacteria growing on control female embryos were scraped off the surface or at least rolled into mats uncovering the embryo surface. Fisher hypothesized that bacteria could kill fouled embryos by physical suffocation, by competition with the embryo for oxygen at its surface, and by pathogenic activity. A more serious result occurred when experimental and control females with recently spawned embryos were exposed to the fungus Lagenidium callinectes. In this instance, all non-groomed embryos became infected by the pathogen and died, whereas control embryos remained free of infection (Fisher 1983b).

Heavy embryo mortality has been reported in the literature for commercially important

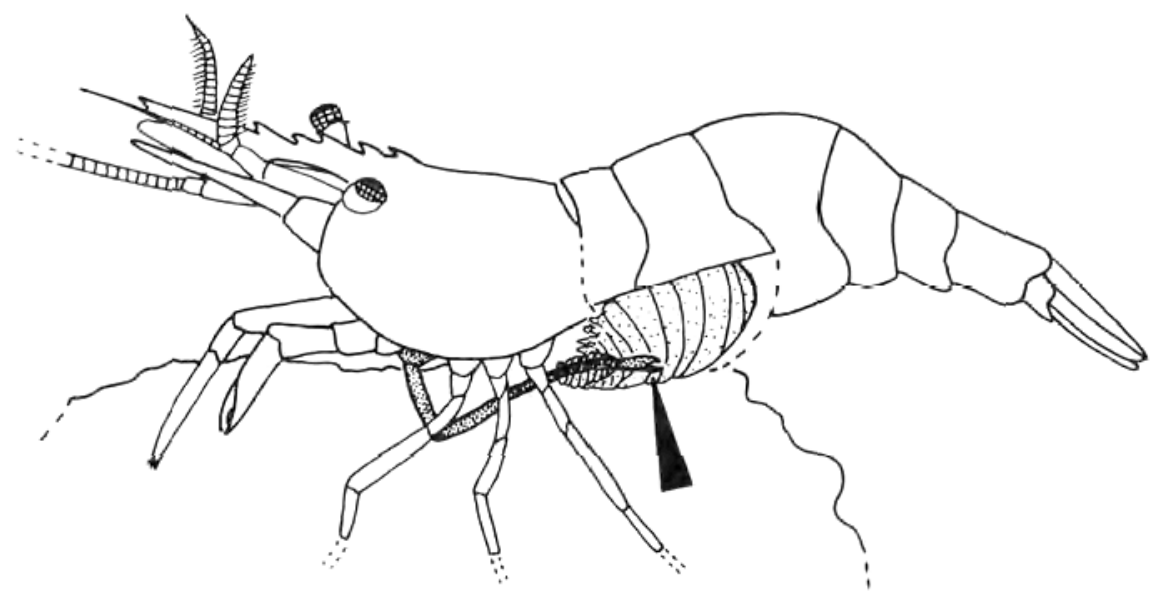

Figure 19. Chelipede grooming of a parasitic isopod, Hemiarthrus abdominalis, by its host, Heptacarpus paludicola. 
crabs such as Cancer magister (Fisher \& Wickham 1976). These authors attributed most of this mortality to epibiontic fouling, but more recently Wickham (Wickham and Kuris 1985, Wickham 1979) suggested that nemertean egg predators are responsible. In Cancer magister, up to $50 \%$ embryo mortality occurred as a result of predation by the nemertean worm Carcinonemertes errans. The intense, precise embryo brushing and preening so easily observed in carideans, stenopodids, and many anomurans has not been reported in brachyuran crabs, and I have not observed it. Fisher (1983a) reports that Cancer magister does not clean its embryos. It is not surprising that, of 56 decapod crustacean species reported to be infested by embryo predators (Wickham \& Kuris 1985), the vast majority are brachyurans, and no carideans or stenopodids are found on the list. Only three species on the list (a hippid, a lithodid, and a galatheid) have a grooming appendage capable of grooming embryos. Aiken \& Waddy (1980) reported high embryo mortality in Homarus broods caused by Carcinonemertes in spite of intensive embryo grooming. This loss might be explained by the very long embryo incubation period (9-11 months) and the large and relatively clumsy (compared to carideans and anomurans) cleaning chelipedes of homarid lobsters. In my experiments on the caridean Heptacarpus pictus (a species with efficient embryo grooming and brushing), I searched for but found no sign of egg predators in broods of experimental females. These observations and the taxonomic distribution of nemertean egg predator hosts given in the literature indicate that embryo predators are not successful on those decapods with welldeveloped embryo-preening behavior.

\subsection{Grooming and parasitism}

Although behavior may reduce the rate of parasitic infection, it does not eliminate parasitism completely. In fact, in many caridean species with well-developed grooming behavior, rates of infestation by large ectoparasitic bopyrid isopods can be quite high (pers. obs., Fig. 19). Ritchie \& Høeg (1981) have analyzed the interaction between grooming behavior and parasitism in the porcellanid crab Petrolisthes cabrilloi. This anomuran suffers high rates of infection by the rhizocephalan cirriped Lernaeodiscus porcellanae. In a number of elegant experiments, Ritchie \& Høeg (1981) demonstrated that the cyprid larva of the parasite settles on the gills, where it rapidly transforms into the small, flat infective stage, the kentrogon. The chelate fifth pereiopods of P.cabrilloi were very effective at eliminating cyprids and kentrogons from the gill chamber. Crabs with amputated grooming appendages suffered heavy infestations. The morphology of the kentrogon (flattened, low profile) is an obvious adaptation to escape the grooming appendage of the host. However, if the parasite does penetrate the host defenses, grooming behavior is not effective at removing it. In fact, the host grooming behavior is necessary for the survival and successful reproduction of the parasite! The adult female parasite emerges, after an internal phase within the host tissues, as the externa below the host abdomen. Ritchie \& Høeg reported that the parasite externa mimics a mass of incubated host embryos; the externa is groomed just as incubated embryos are. This mimicry might explain the feminization of parasitized male crabs, which also groom and aerate the parasite. Parasites not groomed by the host (because of amputation of host grooming appendage) failed to molt properly, became fouled, and died. Removal of the parasite exuvium has to be performed by the host's grooming chelae because the appendageless, bag-like rhizocephalan is unable to complete the task by itself. If the female molt skin is not removed, the openings to its reproductive openings are blocked, male cyprids cannot enter, and reproduction is prevented. The manipulation of host grooming behavior by 
parasites might explain many cases of ectoparasitism in decapods with well developed gill or general body grooming. If the parasite larva can evade the grooming behavior of the host, the adult ectoparasite apparently becomes accepted as part of the host's body (Ritchie, pers. comm.). Figure 19 shows the hippolytid Heptacarpus paludicola grooming the male and female of the bopyrid Hemiarthrus abdominalis, which also appears to mimic an embryo mass. Most bopyrid isopods are found in the branchial chambers of carideans and anomurans, decapods that vigorously brush and clean the gills. The established parasite is apparently considered part of the host body and is groomed, not removed by grooming. Several species of carideans occurring in the vicinity of the University of Washington's Friday Harbor Laboratories show high rates of bopyrid infection (e.g., 20-30\% in H.paludicola, pers. obs.); study of the interaction between bopyrid infection and host grooming behavior should reveal interesting information.

\section{BEHAVIORAL ASPECTS OF GROOMING}

Very little analysis has been done on the behavioral organization or neural control of grooming, and the information I will report is mainly anecdotal. Bauer (1977) did construct ethograms for the caridean Heptacarpus pictus. Antennular grooming by the third maxillipedes is the most stereotyped and most frequently occurring cleaning behavior; durations of bouts are quite short. Gill grooming, general body grooming, and female embryo cleaning are less frequent, but, when they take place, bout length is much longer than in antennular preening. This basic pattern has been observed by me for most carideans, stenopodids, and anomurans, i.e., decapods in which all of these behaviors occur. In other decapods, antennular grooming is usually frequent even though other grooming behaviors are infrequent or absent. Even rather sedentary brachyurans, e.g. majid crabs such as Macroceloma spp. and Loxorhynchus spp., regularly groom antennules. Active brachyurans (e.g. Cronius tumidulus, Fig. 1A) groom and scrub the antennules very often.

The above observations can be related to hypotheses on the adaptive value of different grooming behaviors discussed in the previous section. Antennules are sites of olfaction, a very important source of environmental information in crustaceans. Even short-term fouling of olfactory sites might endanger a decapod's perception of its surroundings (detection of food, predators, mates, etc.). Antennular grooming is therefore frequent. Because the third maxillipedes clean a limited body area (antennules, antennae, and distal ends of the pereiopods), a fixed action pattern, i.e., a behavior of low variability in performance, is sufficient. On the other hand, gill grooming, general body grooming, and embryo cleaning involve the preening of many different body regions of varying, complex topography. These behaviors are much more variable in performance, e.g, a cleaning chelipede constantly modifies its posture and movement to preen different types of structures. These behaviors are less frequent in those decapods in which they occur. For example, a shrimp might tolerate the settlement of an algal spore on its carapace for minutes or hours, but not for longer periods in which an epizoite capable of disrupting swimming could develop. Bouts of general body grooming are much longer than bouts of antennular preening (Bauer 1977), as larger areas of complex form have to be cleaned.

Another generalization, based on anecdotal observations, that needs further substantiation is that more active decapods engage in grooming much more intensively than less active or sedentary ones. For example, Fryer (1977) noted that the alert, frequently swimming atyid 
Xiphocaris elongata groomed much more than the sluggish, more benthic Atya innocous. I have observed this difference in grooming intensity among different species of the hippolytid genus Heptacarpus that vary greatly in body form and general activity (Bauer 1984). A very simple explanation is that more active animals perform all behaviors more frequently than do sedentary ones. However, I have observed that various Atya species, while showing less locomotory activity and general appendage movement than Xiphocaris elongata, nevertheless exhibit feeding behaviors (current filtration or bottom sweeping with the chelipedes) much more frequently than X.elongata. In other words, Atya are actively doing something, but they appear sedentary because they are not moving around. Therefore, there may be real differences in grooming intensity between the two shrimps. Because X.elongata is more mobile and perhaps encounters more diverse environmental situations than do Atya species, it may need to keep sensory sites cleaner than does Atya. As a more active swimmer, it may need to engage in general body grooming frequently to prevent epizoic fouling on its streamlined body. Fryer (1977) reports that the less natatory Atya innocous often endure algal fouling on their bodies.

Little is known about the stimuli that trigger grooming behavior. I have fouled a variety of decapods with sediment, carmine particles, etc. without stimulating grooming. The only successful attempt was with the shrimp Pandalus danae. Fouling or even touching the third maxillipede grooming setae routinely caused an autogrooming reflex. Snow (1973) observed that antennular grooming was stimulated by tapping of the antennule with a glass rod. Decapods often increase antennular grooming when offered food or when in the presence of a mate. Because they also become much more active in these situations, only a sophisticated behavioral analysis would determine whether antennular grooming is actually more frequent (i.e., has been stimulated) compared to other behaviors. The only concrete observation on grooming behavior stimulation is that by Ritchie \& Høeg (1981) in the porcellanid Petrolisthes cabrilloi. The crabs invariably began intensive gill grooming when cyprid larvae (the infective stage) of parasites were introduced into their holding chambers.

Although rigorous experimental studies may reveal the nature of stimuli initiating cleaning, it may be that the frequency and duration of different types of grooming behavior are genetically programmed into the nervous system. Grooming may occur at fixed intervals and rates when not inhibited by other, more pressing behaviors, e.g., food searching, feeding. escape, mating.

\section{PHYLOGENETIC SIGNIFICANCE OF GROOMING}

As with any set of characters, grooming structures and behaviors potentially contain phylogenetic information. An advantage to working with grooming characters is that their function either is known, can be determined experimentally, or can be reasonably hypothesized. This advantage is of great importance when one is trying to decide whether the occurrence of a character in two groups is due to genealogy or convergent evolution. Bauer (1984) has used gill cleaning mechanisms to determine the polarity of evolution in other, nonrelated characters in the caridean genus Heptacarpus. Martin \& Felgenhauer (1986) have reported that, in freshwater aeglid anomurans, grooming characters are genealogically conservative and not subject to convergence related to the freshwater habitat. I certainly do not want to suggest that phylogenies can be created solely on the basis of grooming characters. However, certain grooming characters may be of value because, once lack of 
convergence has been established, they can be used to affirm or contradict phylogenies set up on the basis of other characters. Below, I discuss the phylogenetic significance of different grooming structures.

\subsection{P1-CP Antennal grooming brushes}

The distribution and functional morphology of the pereiopod 1 carpal-propodal (P1-CP) antennal grooming brushes in dendrobranchiate, stenopodid, and caridean shrimps (including Procaris) was given in a previous section. As I have stated before (Bauer 1981), it is very unlikely that the mutual possession of this character by all 'natant' groups is due to convergence. In spite of considerable variation in the morphology of pereiopod 1 among these groups, the brushes do not vary in position. If convergence were involved, one would expect to find similar brushes on other limb segments or even on the second pereiopod in at least some species. There is no apparent functional barrier to the presence of antennal cleaning brushes on other appendages, as is illustrated quite clearly by Stenopus hispidus (Fig. 3). During antennal flagellar grooming, the pereiopod 2 acts on the flagellum much like pereiopod 1, but grooming brushes are only developed on pereiopod 1 .

In members of the infraorders Thalassinidea, Astacidea, Palinura, Anomura, and Brachyu$\mathrm{ra}$, the P1-CP brushes are absent. These decapods generally groom the antennular flagella with the third maxillipedes. Likewise, in members of 2 of 15 caridean families, these brushes have been lost, and antennal flagellar grooming is performed with the third maxillipedes. Even in some carideans with the P1-CP brushes, the third maxillipedes participate in antennal grooming. My point is that the $\mathrm{P} 1-\mathrm{CP}$ brushes are not essential to antennal grooming and that their function is easily supplied by the third maxillipedes.

My present view (contrary to that of Bauer 1978) is that the P1-CP brushes are accessory grooming brushes not subject to constant and significant selection pressure. Therefore, their presence in various groups reflects genealogy. Two hypotheses can be proposed. First, as suggested by Bauer (1981), the P1-CP antennal grooming brushes are shared derived characters that support the view of a common ancestor to the group Natantia (peneoids and sergestoids; carideans, including Procaris; and stenopodids) (see Felgenhauer \& Abele $1983 \mathrm{~b}$ for history of the taxon Natantia). The morphology of Procaris, a caridean with peneoid and stenopodid features (Chace \& Manning 1972), supports this view; if Procaris reproduction does not involve embryo incubation, the view of the Natantia as a natural unit will gain further support. However, Burkenroad's (1963) argument for separate dendrobranchiate (peneoids and sergestoids) and pleocyemate (all other decapods) lines of evolution is convincing (but see Burkenroad 1981 for separation of pleocyemate lineages) and in conflict with the idea of a natural taxon, Natantia. Another hypothesis that would be in accord with either of Burkenroad's $(1963,1981)$ views on decapod evolution is that the $\mathrm{P} 1-\mathrm{CP}$ brushes are primitive; i.e., the ancestral decapod had these structures, which have been lost in the 'reptant' groups. The first pereiopods of reptants are often relatively large chelipedes not well adapted to the use of the delicate carpal-propodal brushes found in natant types; antennal flagella are frequently reduced in size. Perhaps the P1-CP brushes were inadaptive for grooming in reptants and have been lost.

\subsection{Gill cleaning mechanisms}

Setiferous thoracic epipods appear to be the ancestral gill cleaning mechanism in decapods and are found today on the third maxillipedes and pereiopods of dendrobranchiates, palinu- 
rids, and nephropid lobsters. In the Brachyura, setiferous gill cleaning epipods occur on (all) the maxillipedes only, and this is yet another character confirming brachyuran monophyly. It is interesting to note that, in the archaeobrachyuran Homola faxoni, setiferous epipods still remain on the anterior pereiopods, vestiges from an ancestor with more numerous setiferous epipods. Setobranchs are considered derivatives of epipods (Borradaile 1907). In the infraorder Astacidea, the nephropid lobsters have the more primitive gill-cleaning mechanism (setiferous epipods), whereas the astacoid crayfishes possess setobranchs.

Chelipede brushing of gills is clearly the most derived gill-cleaning condition in the Decapoda. In carideans, epipod-setobranch gill cleaning and chelipede brushing are usually mutually exclusive on the family level. However, in the Hippolytidae, some species use both mechanisms, although epipod-setobranchs are generally reduced. In Heptacarpus, behavioral observations reveal a negative correlation between the development of epipodsetobranch complexes and the intensity of chelipede gill brushing (see also Bauer 1984).

If the infraorders Thalassinidea and Anomura (sensu Bowman \& Abele 1982) are considered together, one can observe a series of changes in the cephalothorax and fifth pereiopod that may represent a phylogenetic series. In the axiid thalassinideans, the carapace is tightly clamped around the cephalothorax, setobranchs are used for gill cleaning, and the nonchelate fifth pereiopods, which have propodal grooming brushes, are little reduced and not held dorsally. Callianassid and upogebiid fifth pereiopods are chelate and can reach into and groom the gills; neither setobranchs nor setiferous epipods occur. Members of the Anomura can tilt the carapace forward so that reduced, dorsally carried, chelate fifth pereiopods, completely modified as grooming appendages, easily groom the gills; setobranchs are always absent in the Anomura. The Thalassinidea and Anomura have often been grouped together or at least considered to be allied. Burkenroad (1963) presented evidence that a thalassinid-like decapod was ancestral to the Anomala (Galtheoidea, Hippoidea, Paguroidea). An ancestral form might be proposed with an axiid-like pereiopod 5, carapace, and setobranchs. Loss of setobranchs and their replacement as a gill-cleaning mechanism by pereiopod 5 (with the concomitant morphological changes in pereiopod 5 and carapace enclosure of the cephalothorax) has resulted in the callianassid, upogebiid, and anomuran conditions described above.

\subsection{General body grooming}

It is difficult to attach much phylogenetic importance, at least at higher taxonomic levels, to general grooming brushes and chelipedes in decapod groups. Many decapods use anterior chelipedes and propodal brushes on the last pereiopod for general body grooming, but it is likely that these are highly subject to convergence. For example, the fifth pereiopod has propodal grooming brushes in a variety of decapod groups; the location of brushes on the last leg is probably due to its proximity to the abdomen, which it grooms, and not to phylogeny. Decapod chelae, often used in grooming, are highly subject to convergence (Burkenroad 1963). On the other hand, within the Caridea, the pereiopod 5 dactylar comb of Atyidae is unique and a shared derived character of the group. General body grooming features are generally conservative at the family level in carideans (Bauer 1978), and thus variation within a family might be used in phylogenetic studies. More extensive studies on the distribution and variation of general grooming characters should be done on the lower taxonomic levels; i.e.. there is not yet enough basic data for drawing further conclusions. 


\section{ACKNOWLEDGMENTS}

The first draft of this manuscript was written and submitted when the author was a faculty member of the Department of Biology, University of Puerto Rico (UPR), Rio Piedras. I acknowledge the financial support of OCEGI and FIPI grants from the Office of Academic Affairs, UPR Rio Piedras. I thank Dr. Zwi Weiss (UPR Rio Piedras) for the many hours of access to the SEM facility and also Oscar Resto and Carlos Rivera for their patient help in making the SEM micrographs. Many of the behavioral observations were carried out at the Isla Magueyes Marine Laboratory, UPR Mayagüez; I gratefully acknowledge the help of Professor Charles Cutress for logistical support and for sharing his time and his knowledge about the whereabouts of various decapods. I thank Joel W. Martin and Bruce E.Felgenhauer for their valuable editorial assistance. This is Contribution 10 of the Center for Crustacean Research.

\section{REFERENCES}

Aiken, D.E. \& S.L. Waddy 1980. Reproductive biology. In J.S.Cobb \& B.F.Phillips (eds.), The Biology and Management of Lobsters, Vol. 1: pp. 215-276. New York: Academic Press.

Bauer, R.T. 1975. Grooming behaviour and morphology of the caridean shrimp Pandalus danae Stimpson (Decapoda: Natantia: Pandalidae). Zool. J. Linn.Soc. 56:45-71.

Bauer, R.T. 1976. Antifouling adaptations of caridean shrimp: grooming morphology and behavior. Doctoral dissertation, Scripps Institution of Oceanography, University of California, San Diego. 269 pp.

Bauer, R.T. 1977. Antifouling adaptations of marine shrimp (Crustacea: Decapoda: Caridea): functional morphology and adaptive significance of antennular preening by the third maxillipeds. Mar. Biol. 40:260-276.

Bauer, R.T. 1978. Antifouling adaptations of caridean shrimp: cleaning of the antennal flagcllum and general body grooming. Mar. Biol. 49:69-82.

Bauer, R.T. 1979. Antifouling adaptations of caridean shrimp (Decapoda: Caridea): gill cleaning mechanisms and grooming of brooded embryos. Zool. J. Linn. Soc. 65:281-303.

Bauer, R.T. 1981. Grooming behavior and morphology in the decapod Crustacea. J. Crust. Biol. 1:153-173.

Bauer, R.T. 1984. Morphological trends in the genus Heptacarpus (Decapoda, Caridea) and their phylogenetic significance. J. Crust. Biol. 4:201-225.

Borradaile, L.A. 1907. On the classification of the decapod crustaceans. Ann. Mag. Nat. Hist. London (7):457-45.

Bowman, T. \& L.G.Abele 1982. Classification of the Crustacea. In L.G. Abele (ed.), The Biology of Crustacea, Vol. 1: pp. 1-27. New York: Academic Press.

Burkenroad, M.D. 1934. The Penaeidea of Louisiana with a discussion of their world relationships. Bull. Amer. Mus. Nat. Hist. 68:61-143.

Burkenroad, M.D. 1963. The evolution of the Eucarida (Crustacea, Eumalacostraca) in relation to the fossil reco-d. Tulane Stud. Geol. 2:2-17.

Burkenroad, M.D. 1981. The higher taxonomy and evolution of Decapoda (Crustacea). Trans. San Diego Soc. Nat. Hist. 19:251-268.

Calman, W.T, 1909. Crustacea. Part VII, Third Fascicle, of E.R.Lankester (ed.), A Treatise on Zoology. London: Adam \& Charles Black.

Chace, F.A.,Jr. \& R.B.Manning 1972. Two new caridean shrimps, one representing a new family, from marine pools on Ascension Island (Crustacea: Decapoda: Natantia). Smith. Contr.Zool., No. 131, 18pp.

Derby, C.D. 1982. Structure and function of cuticular sensilla of the lotster Homarus americanus. J. Crust. Biol. 2:1-21.

Efford, I.E. 1971. The antennule cleaning setae in the sand crab, Emerita analoga (Stimpson) (Decapoda Anomura). Crustaceana. 10:167-182.

Factor, J.R. 1978. Morphology of the mouthparts of larval lobsters, Homarus americanus (Decapoda: Nephropidae), with special emphasis on their setae. Biol. Bull. 154:383-408.

Farmer, A.S. 1974a. The functional morphology of the mouthparts and pereiopods in Nephrops norvegicus (L.) (Decapoda: Nephropidae). J.Nat. Hist. 8:121-142.

Farmer, A.S. 1974b. Reproduction in Nephrops norvegicus (Decapoda: Nephropidae). J. Zool. London 174:161183.

Felgenhauer, B.E. \& L.G.Abcle 1983a. Ultrastructure and functional morphology of feeding and associated appendages in the tropical fresh-water shrimp Atya innocous (Herbst) with notes on its ecology. J. Crust. Bıol. 3:336-363. 
Felgenhauer, B.E. \& L.G.Abele 1983b. Phylogenetic relationships among shrimp-like decapods. Crustacean Issues 1: 291-311.

Felgenhauer, B.E. \& F.R.Schram 1978. Differential epibiont fouling in relation to grooming behavior in Palaemonetes kadiakensis. Fieldiana: Zool. 72:83-100.

Felgenhauer, B.E. \& F.R. Schram 1979. The functional morphology of grooming appendages of Palaemonetes kadiakensis Rathbun, 1902. Fieldiana: Zool. (n.s.) 2:1-17.

Fisher, W.S. 1983a. Eggs of Palaemon macrodactylus. 11. Association with aquatic bacteria. Biol. Bull. 164:201213.

Fisher, W.S. 1983b. Eggs of Palaemon macrodactylus. III. Infection by the fungus, Lagenidium callinectes. Biol. Bull. 164:214-226.

Fisher, W.S. \& D.E. Wickham 1976. Mortalities and epibiotic fouling of eggs from wild populations of the Dungeness crab, Cancer magister. Fish. Bull. 74:201-207.

Fryer, G. 1960. The feeding mechanism of some atyid prawns of the genus Caridina. Trans. Roy. Soc. Edin. 64:217-244.

Fryer, G. 1977. Studies on the functional morphology and ecology of the atyid prawns of Dominica. Phil. Trans. Roy. Soc. London. (B) Biol. Sci. 277:57-129.

Glaessner, M.F. 1960. The fossil decapod Crustacea of New Zealand and the evolution of the order Decapoda. New Zeal. Geol. Surv. Paleon. Bull. 31:63.

Glynn, P.W. 1970. Growth of algal epiphytes on a tropical marine isopod. J. Exp. Mar. Biol. Ecol. 5:88-93.

Hiatt, R.W. 1948. The biology of the lined shore crab, Pachygrapsus crassipes Randall. Pac. Sci. 2:135-213.

Holmquist, J.G. 1982. The functional morphology of gnathopods: importance in grooming, and variation with regard to habitat, in talitroidean amphipods. J. Crust. Biol. 2:159-179.

Holmquist, J.G. 1985. The grooming behavior of the terrestrial amphipod Talitroides alluaudi. J. Crust. Biol. 5:334-340.

Huxley, T.H. 1880. The Crayfish: An Introduction to the Study of Zoology. New York: D. Appleton and Co.

Kaestner, A. 1970. Invertebrate Zoology. Vol. 3. New York: Interscience Publ.

Martin, J.W. \& B.E.Felgenhauer 1986. Grooming behaviour and the morphology of groorning appendages in the endemic South American crab genus Aegla (Decapoda, Anomura, Aeglidae). J. Zool. London 209:213-224.

MacGinitie, G.E. 1930. The natural history of the mud shrimp Upogebia pugettensis(Dana). Ann. Mag. Nat, Hist. (10)6:36-44.

MacGinitie, G.E. 1934. The natural history of Callianassa californiensis Dana. Amer.Midl. Nat. 15:166-177.

Phillips, B.F., J.S.Cobb \& R.W.George 1980. General biology. In J.S.Cobb \& B.F.Phillips (eds.), The Biology and Management of Lobsters. Vol. 1: pp. 2-84. New York: Academic Press.

Reese, E.S. 1983. Evolution, neuroethology, and behavioral adaptations of crustacean appendages. In S.Rebach \& D.W.Dunham (eds.), Studies in Adaptation: The Behavior of Higher Crustacea: pp. 57-81. New York: John Wiley \& Sons.

Ritchie, L.E. \& J.T.Høeg 1981. The life history of Lernuevdiscus porcellanae (Cirripedia: Rhizocephala) and cocvolution with its porcellanid host. J. Crust. Biol. 1:334-347.

Roberts, M.H. 1968. Functional morphology of mouthparts of the hermit crabs, Pagurus longicarpus and Pagurus pollicaris. Chesapeake Sci. 9:9-20.

Schembri, P.J. 1982a. Functional morphology of the mouthparts and associated structures of Pagurus rubricatus (Crustacea: Decapoda: Anomura) with special reference to feeding and grooming. Zoomorphology 101:17-38.

Schembri, P.J. 1982b. The functional morphology of the feeding and grooming appendages of Ebalia tuberosa (Pennant) (Crustacea: Decapoda: Leucosiidae), J, Nat, Hist, 16:467-480.

Snow, P.J. 1973. The antennular activities of the hermit crab Pagurus alaskensis (Benedict). J. Exp. Bio! 58:745-765.

Stewart, J.E. 1980. Diseases. In J.S.Cobb \& B.F.Phillips (eds.), The Biology and Management of Lobsters. Vol. 1: pp. 301-344. New York: Academic Press.

Thomas, W.J. 1970. The setae of Austropotamobius pallipes (Astacidae). J.Zool. London 160:91-142.

Vuillemin, S. 1967. La respiration chez crustacés décapodes. Ann. Biol. Ser. (4)6:47-82.

Walker, G. 1974. The occurrence, distribution and attachment of the pedunculate bamacle Octolasmis mülleri (Coker) on the gills of crabs, particularly the blue crab, Callinectes sapidus Rathbun. Biol. Bull. 147:678-689.

Wamer, G.F. 1977. The Biology of Crabs. New York: Van Nostrad Co.

Wasserthal, V.L.T. \& U.Seibt 1976. Feinstrukture, Funktion und Reinigung der antennalen Sinneshare der Garnele Hymenocera picta (Gnathophyllidae). Zeit. Tierpsy. 42:186-199.

Wickham, D.E. 1979. Carcinonemertes errans and fouling in the eggs of the Dungeness crab. J. Fish. Res. Board Can. 36:1319-1324.

Wickham, D.E. \& A.M.Kuris 1985. The comparative ecology of nemertean egg predators. Amer. Zool. 25:127134.

Zimmerman, K. 1913. Habit and habitat in Galatheidea: a study in adaptation. J. Mar, Biol. Assoc, U.K. 10:84-101. 

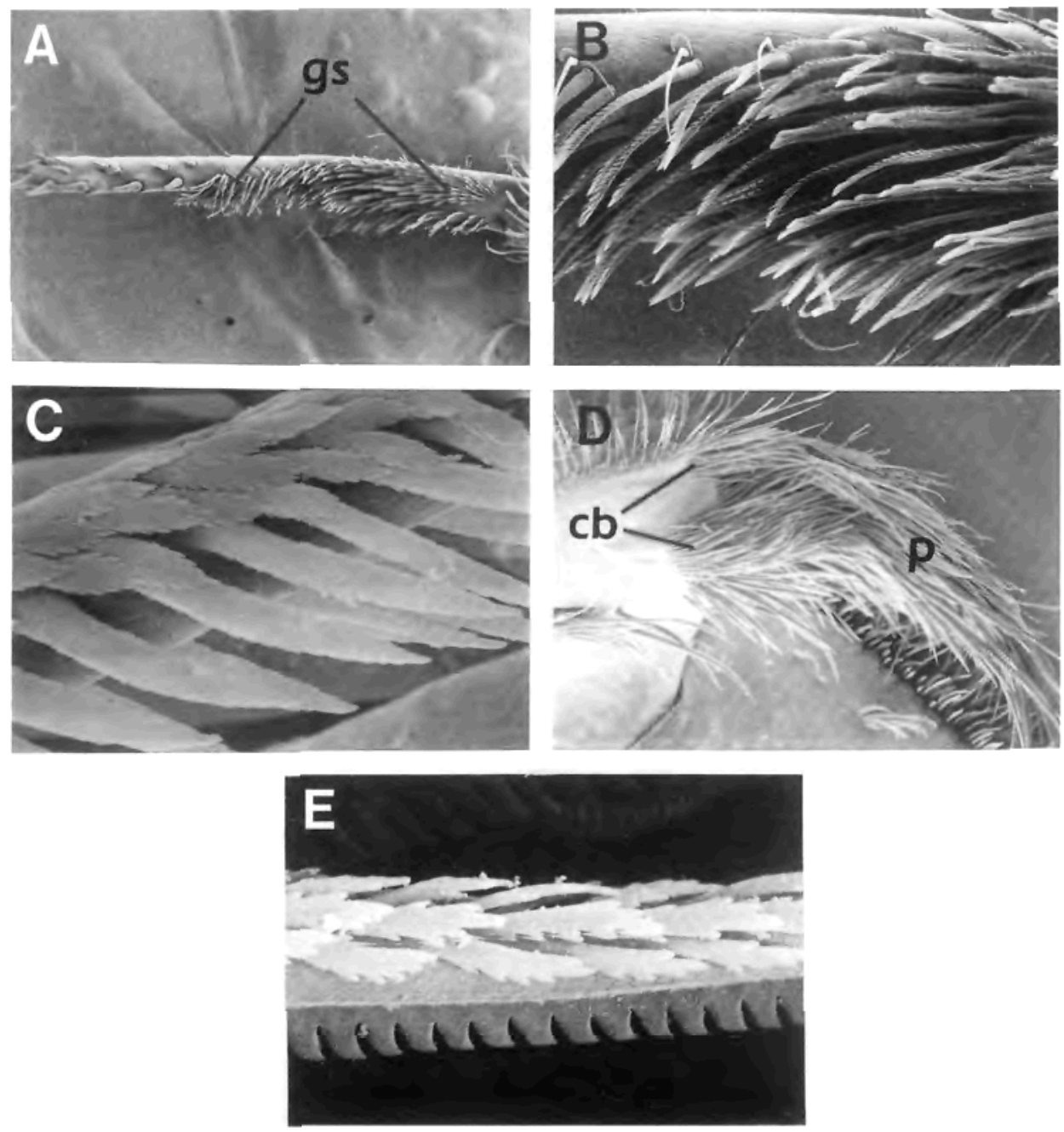

Figure 4. A. Medial view, third maxillipede, Xiphocaris elongata; leaders indicate extent of rows of grooming setae $(\mathrm{gs}) ; \times 18$. B. Enlargement of rows of grooming setae shown in A; $\times 97$. C. Enlargement of shaft of a grooming seta from B; $\times 2430$. D. Medial view of third maxillipede palp, Cronius tumidulus; leaders denote carpal grooming brushes $(\mathrm{cb})$; p - propodus; $\times 39$. E. C.tumidulus carpal brush seta magnified; $\times 4860$. 

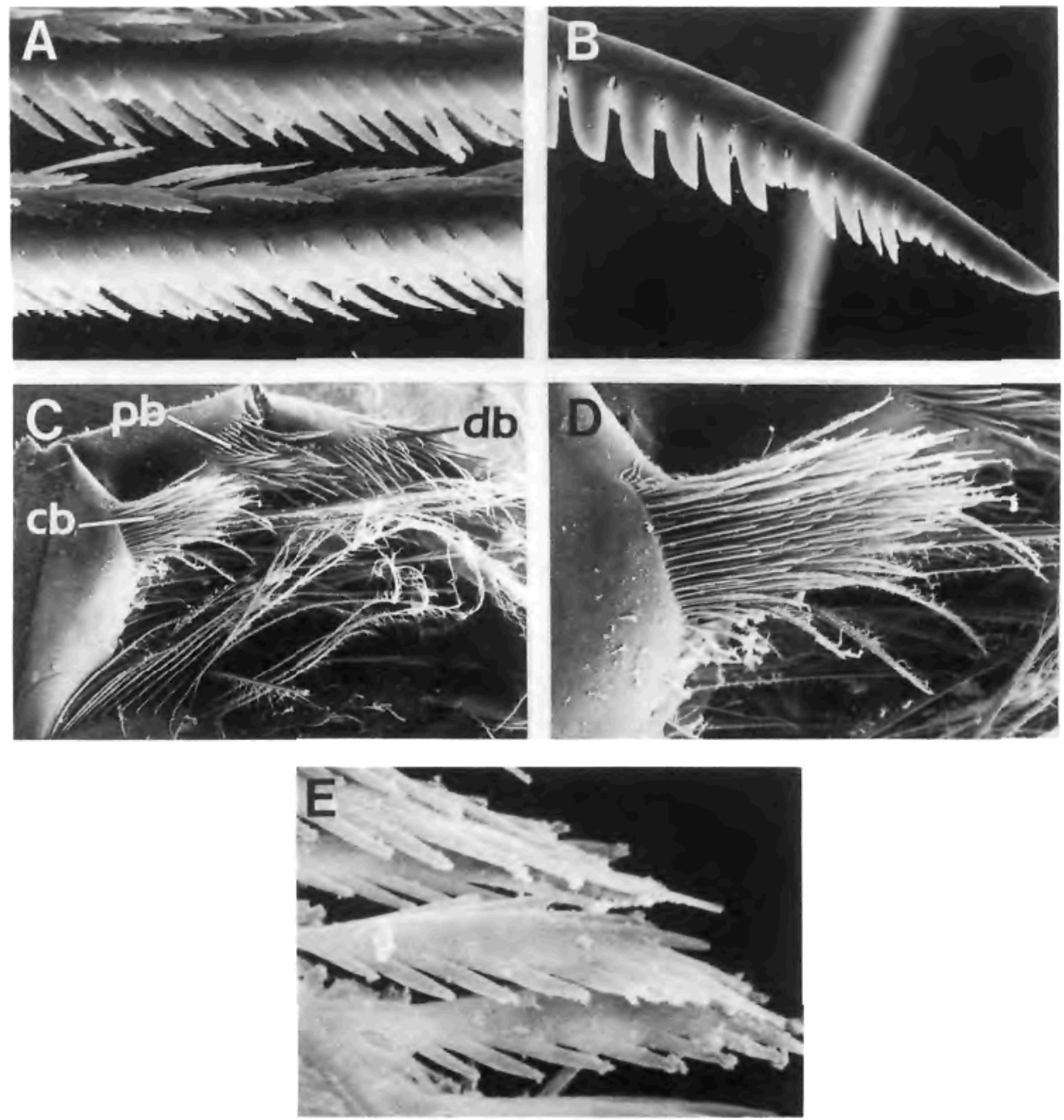

Figure 5. A. Enlargement of setae found on proximal half of propodus, Cronius tumidulus third maxillipede; $\times$ 1782. B. Serrate seta from distal end of third maxillipede propodus, C.tumidulus; $\times 583$. C. Medial view, third maxillipede, Petrolisthes galathinus; leaders indicate carpal grooming brush (cb), propodal brush (pb), and dactylar brish $(\mathrm{db}) ; \times 39$. D. Carpal grooming brush, P.galathinus; $\times 97$. E. Enlargement of complex setules from P.galathinus carpal brush seta; $\times 6966$. 

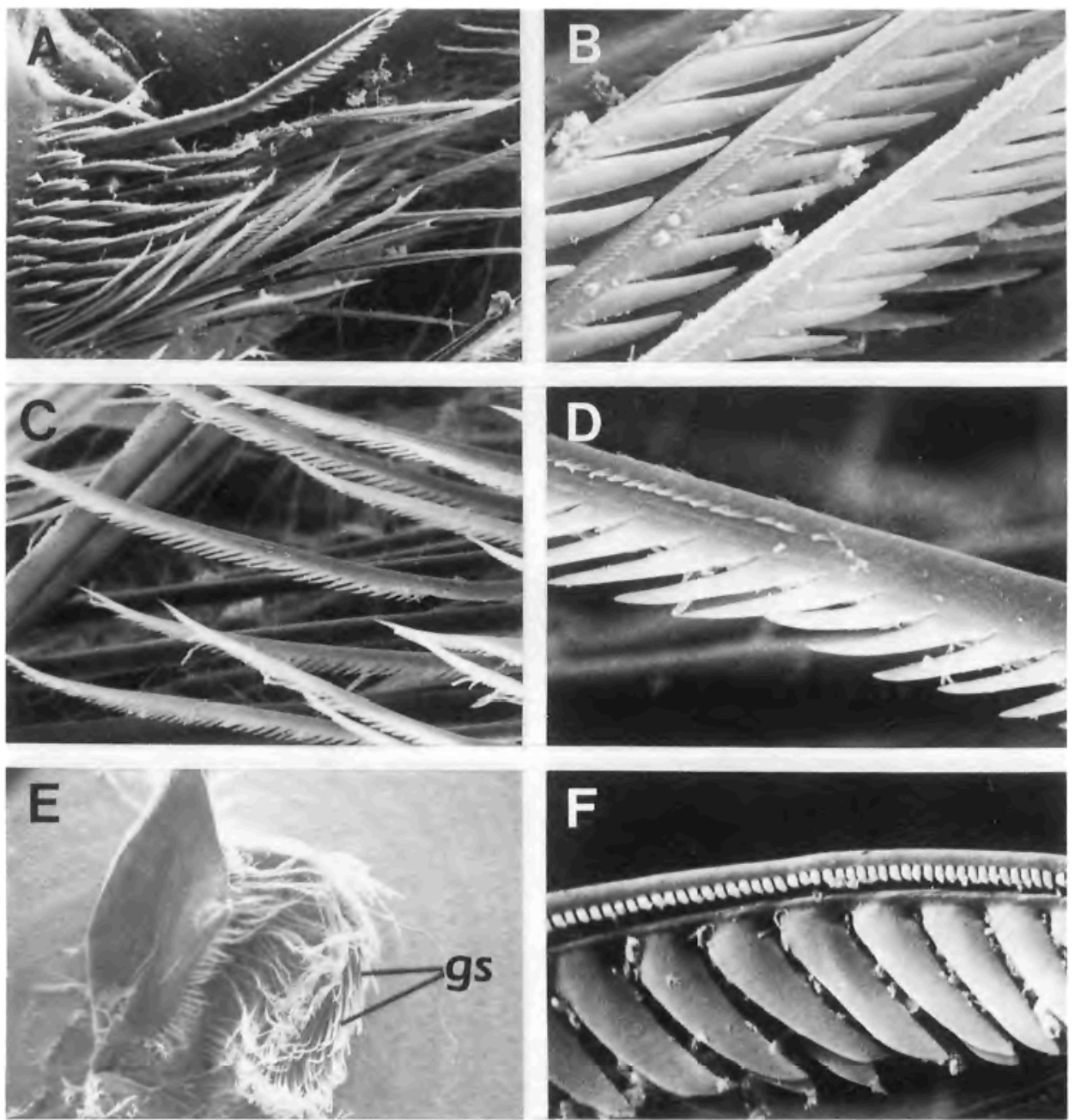

Figure 6. A. Propodal brush, third maxillipede, Petrolisthes galathinus; $\times 162$. B. Enlargement of propodal brush seta from A; $\times 1620$. C. Serrate setae from third maxillipede dactylar brush, P.galathinus $; \times 437$. D. Enlargement of a dactylar brush seta from C; $\times 1944$. E. Medial view, second maxillipede of P.galathinus; leaders indicate location of antennular grooming setae (gs); $\times 32$. F. Enlargement of seta indicated by leaders in E, from second maxillipede of P.galathinus; $\times 2430$. 

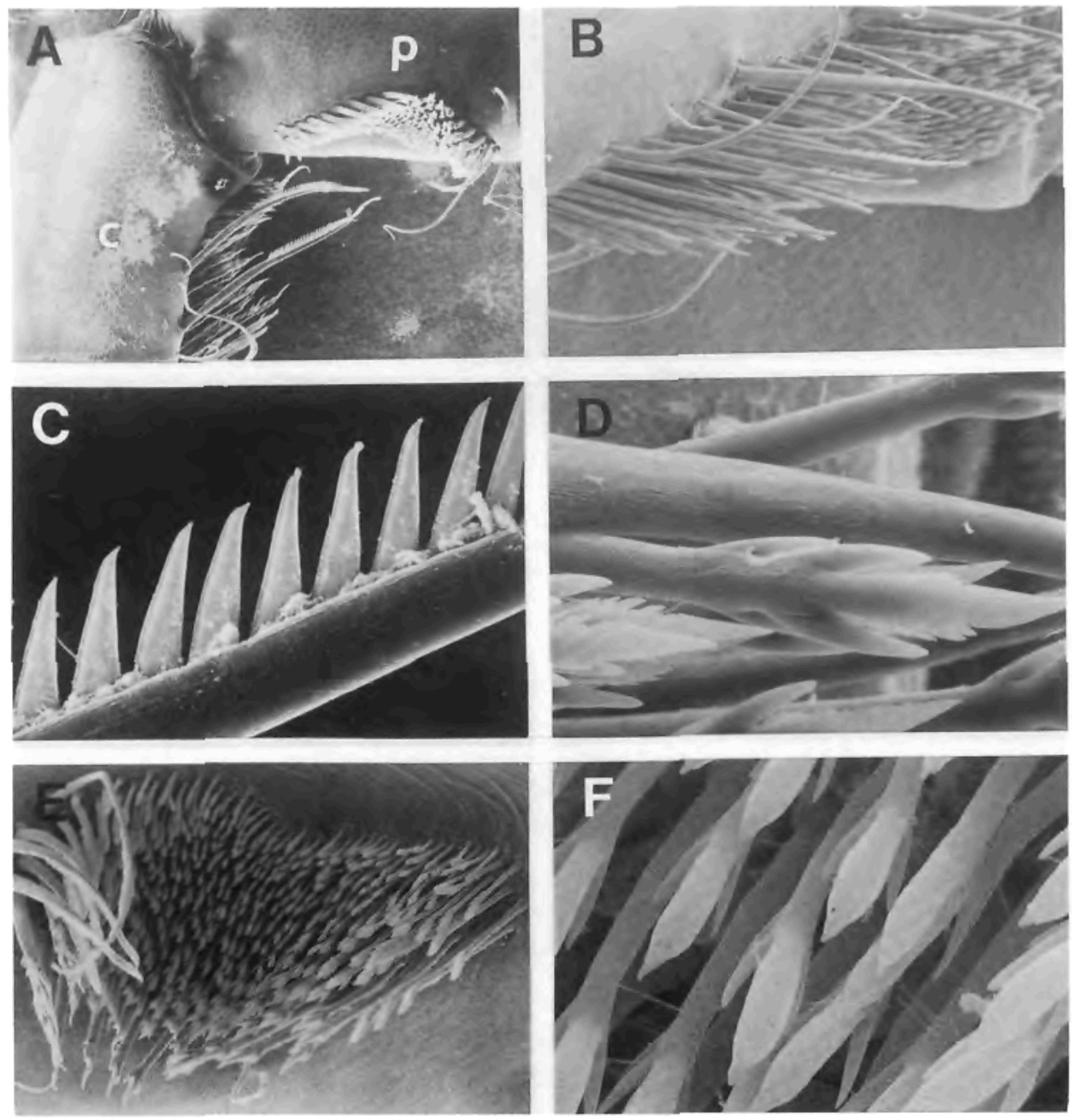

Figure 7. A. Medial view, carpal-propodal joint, pereiopod 1, Stenopus hispidus, showing the P1-CP antennal grooming brushes; c - carpus; $\mathbf{p}$ - propodus; $\times 70$. B. Enlargement of carpal brush shown in $\mathrm{A} ; \times 122$. C. Magnification of long serrate carpal brush seta from A; $\times 1296$. D. Enlargement of short carpal brush seta from A; $\times 1000$. E. Pereiopod 1 propodal brush, S.hispidus; $\times 162$. F. Enlargement of central region of propodal brush shown in $\mathrm{E} ; \times 1620$. 

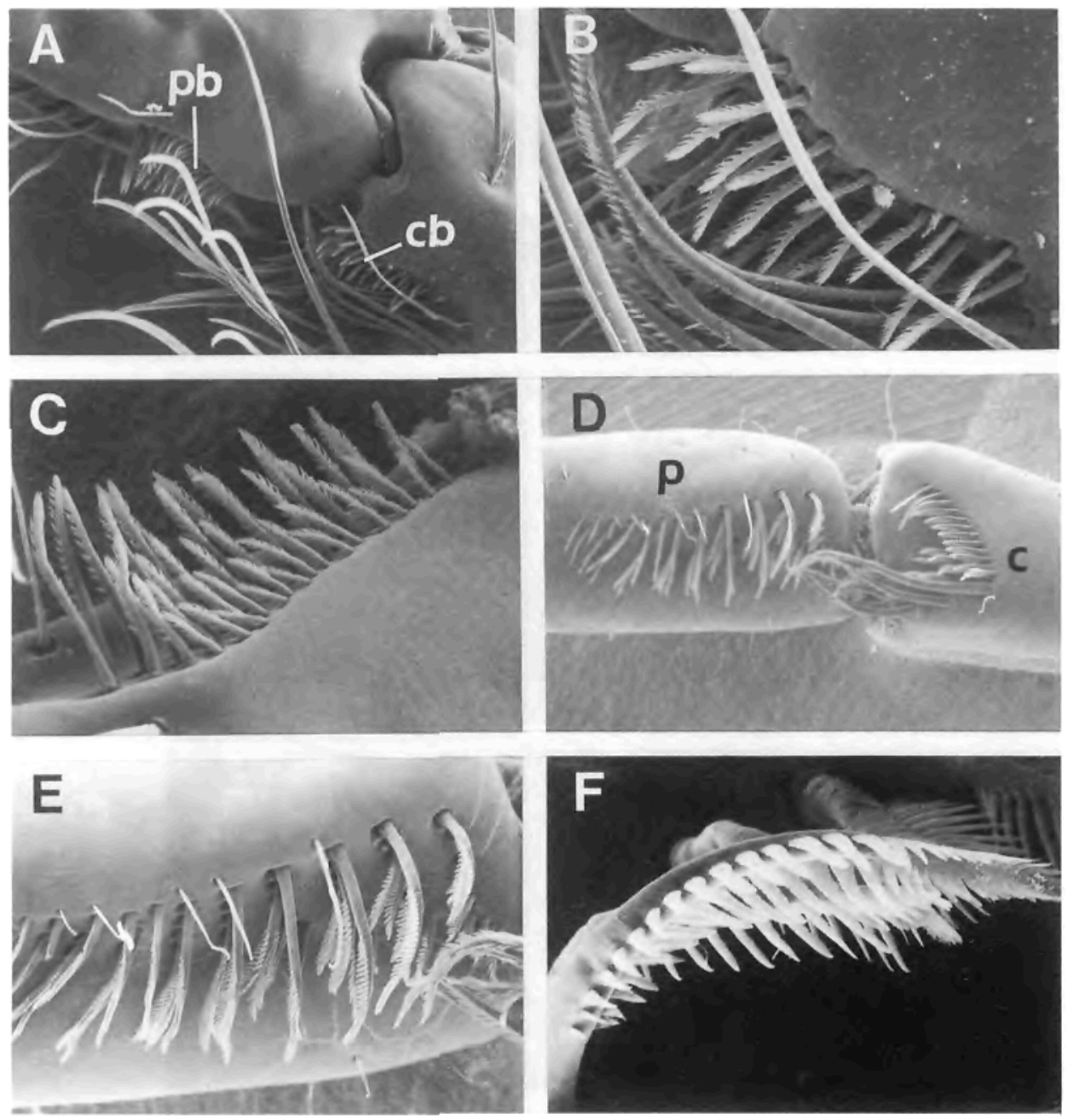

Figure 8. A. Medial view, carpal-propodal joint, pereiopod 1, Metapeneopsis martinella; $\mathrm{cb}$ - carpal brush; pb propodal brush; $\times 81$. B. Enlargement of carpal brush from A; $\times 292$. C. Magnification of propodal brush from A; proximal is to right in this orientation; $\times 259$. D. Medial view, carpal-propodal joint, pereiopod 1 , Leanaier tenuicornis; $\mathrm{c}$ - carpus; $\mathrm{p}$ - propodus; $\times 63$. E. L.tenuicornis propodal brush from $\mathrm{D} ; \times 130$. F. Enlargement of propodal brush seta from $\mathrm{E} ; \times 810$. 

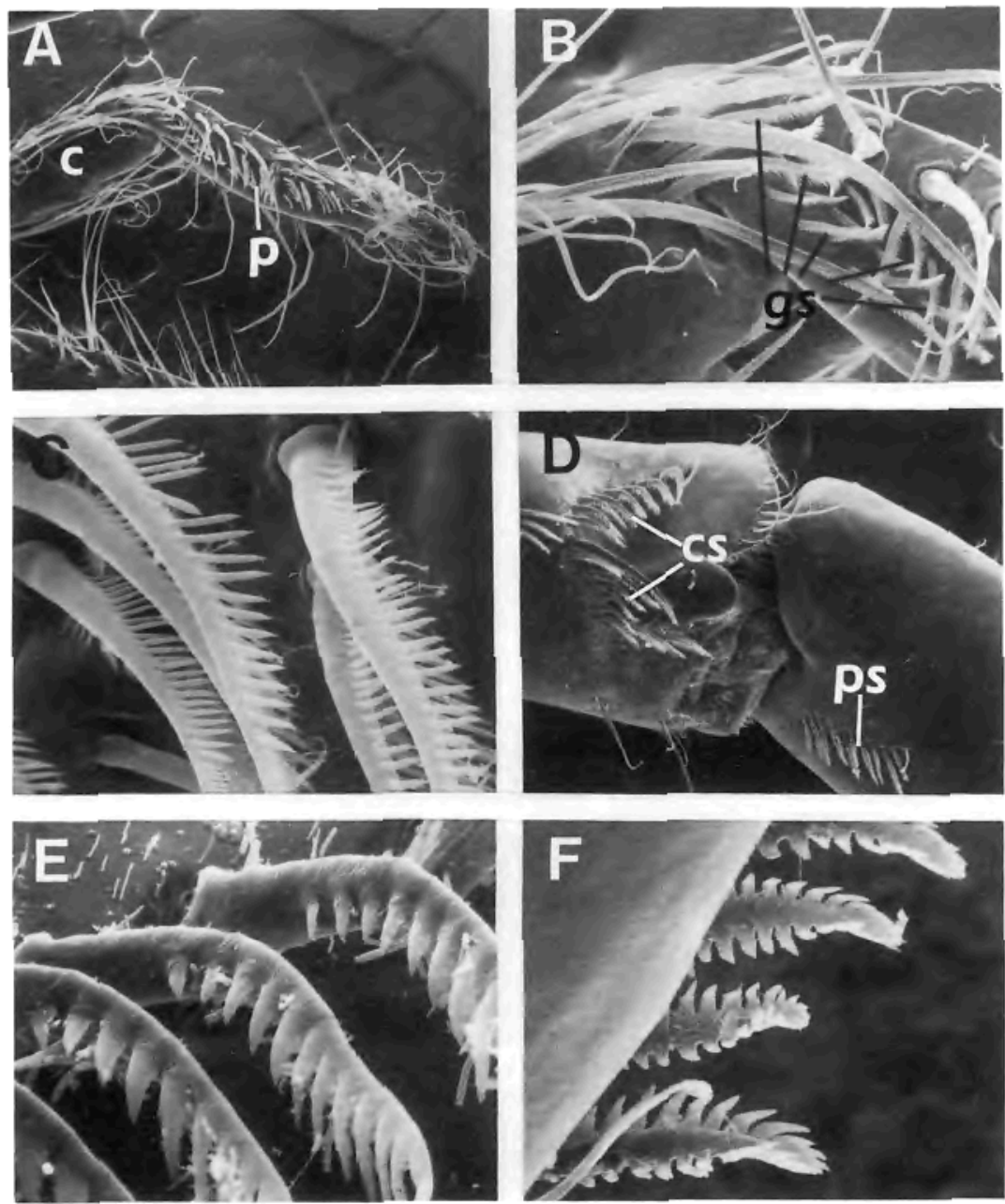

Figure 9. A. Medial view, pereiopod 1, Procaris hawaiana; c - carpus; $\mathrm{p}-$ propodus; $\times 40$. B. Pereiopod 1 carpal-propodal joint, P.hawaiana; leaders indicate various setae (gs) believed to groom antennal flagellum; $\times 152$. C. Enlargement of propodal grooming setae from B; $\times 1620$. D. Medial view, pereiopod 1 carpal-propodal joint, Heptacarpus pictus; cs - carpal antennal grooming setae; ps - propodal antennal grooming setae; $\times 73$. E. Enlargement of carpal grooming setae from D; $\times 243$. F. Enlargement of propodal grooming setae, pereiopod 1, H.pictus; $\times 688$. Figure 9 is made up from original SEM micrographs used in various figures by Bauer (1976). 

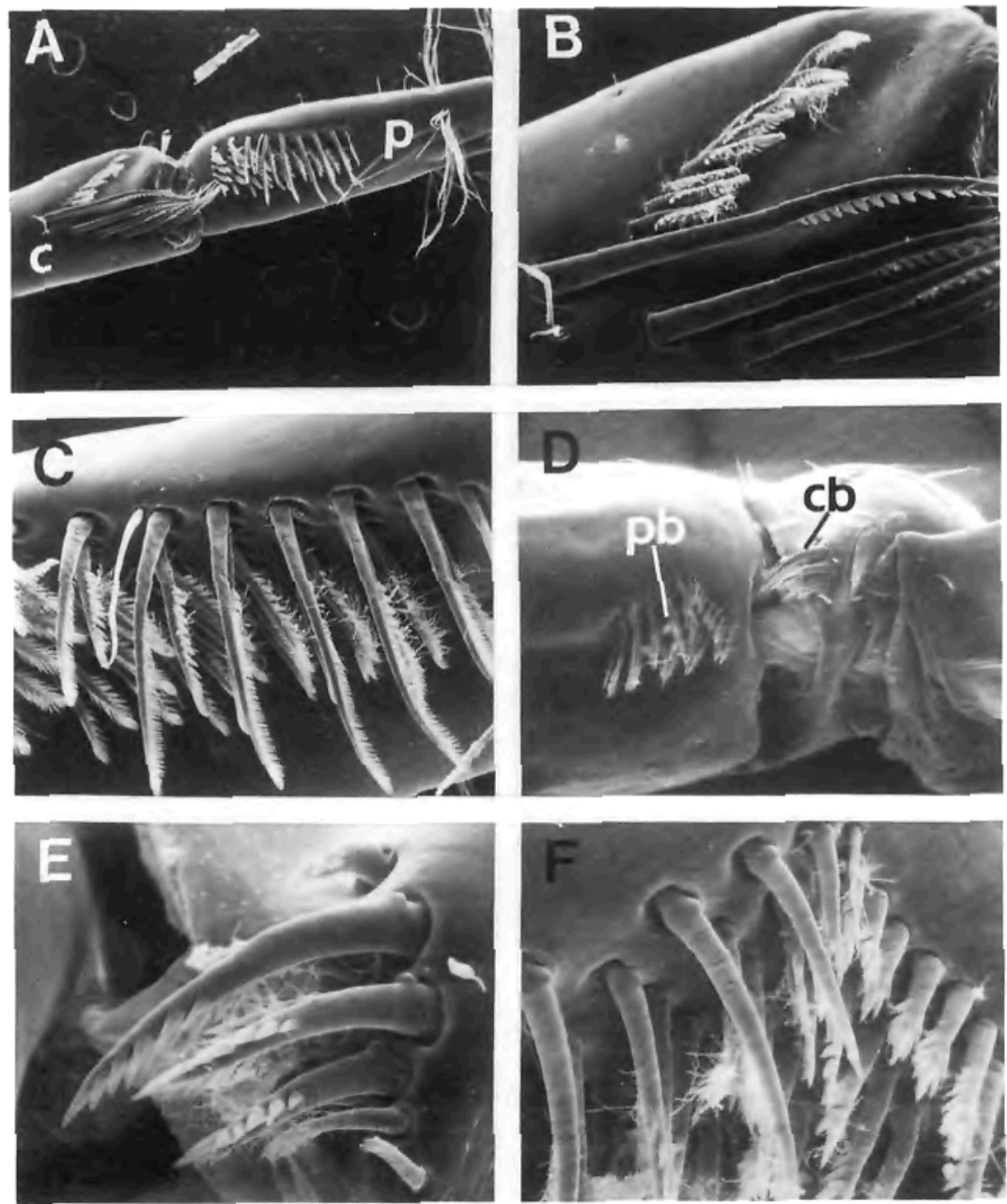

Figure 10. A. Medial view, pereiopod 1 carpal-propodal joint, Palaemon ritteri; $\mathrm{c}$ - carpus; $\mathrm{p}$ - propodus; $\times 40$. B. Carpal brush from A; $\times 162$. C. Propodal brush from A; $\times 162$. D. Medial view, pereiopod 1 carpal-propodal joint, Crangon nigricauda; $\mathrm{cb}$ - carpal brush; $\mathrm{pb}$ - propodal brush; $\times 73$. E. Enlargement of carpal brush from $\mathrm{D} ; \times 364 . \mathrm{F}$. Enlargement of propodal brush from D; $\times 364$. Figure 10 is made up from original SEM micrographs used in various figures by Bauer (1976). 

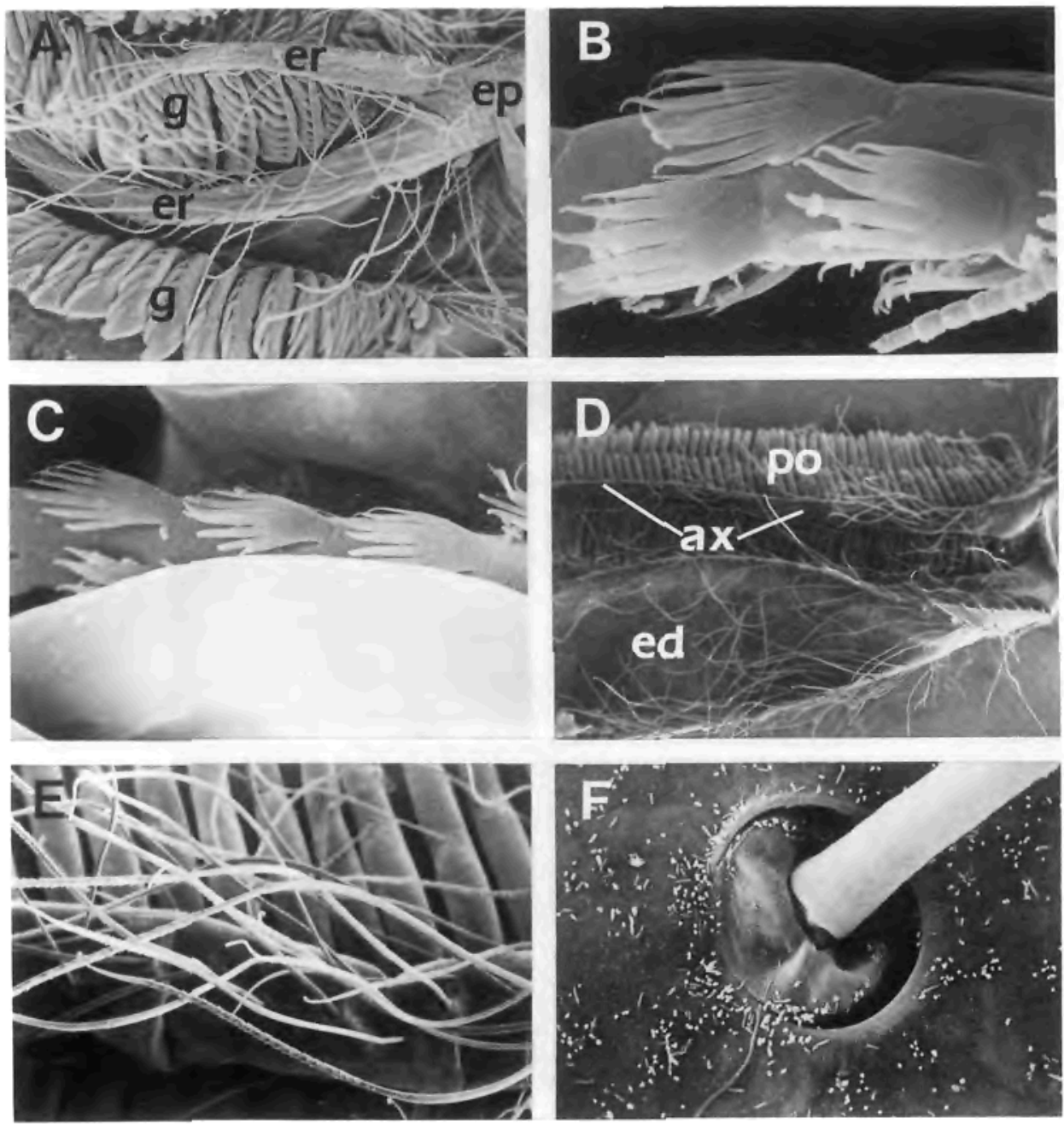

Figure 11. A. Gills and epipod, Sicyonia parri; epipod peduncle (ep) attached to coxa of pereiopod (to right, outside of micrograph); note how epipod rami (er) lie over and between gills ( $\mathrm{g}$ ); observe many long gill-cleaning setae arising from epipod rami; $\times 58$. B. Enlargement of setal shaft of S.parri epipodal gill-cleaning seta (from A), showing characteristic digitate scale setules; $\times 4374$. C. S.parri epipodal gill-cleaning setae located between two adjacent gill rami; $\times 2592$. D. Panulirus argus pereiopodal epipod (ed) and podobranch (po); note many gill-cleaning setae both on epipod and on central axis (ax) of podobranch; proximal is to right in micrograph; $\times 19$. E. Enlargement of podobranch central axis with many gill-cleaning setae, from $\mathrm{D} ; \times 105$. F. Base and socket of epipodal gill-cleaning seta, P.argus $; \times 1620$. 

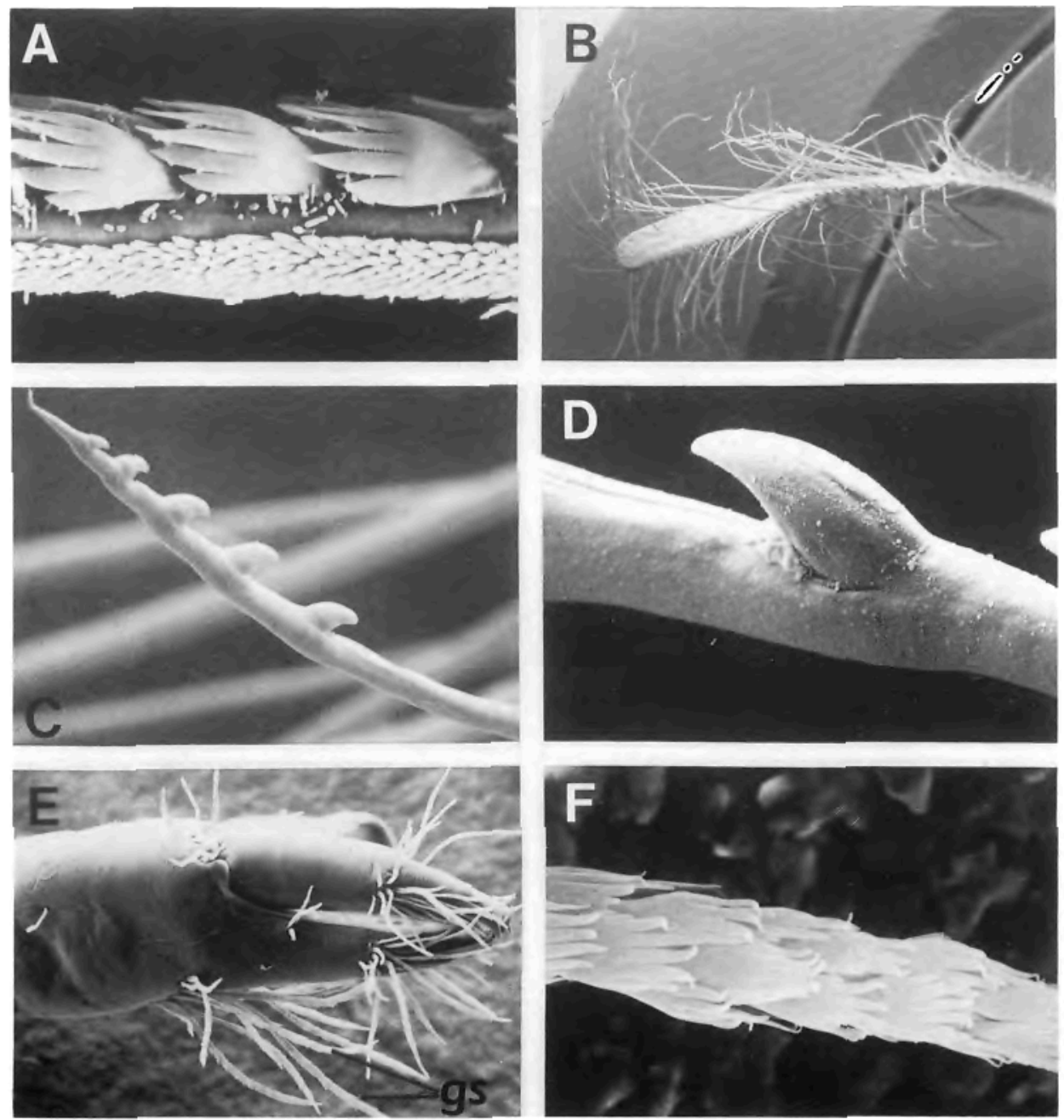

Figure 12. A. Magnification of setal shaft, Panulirus argus epipodal gill-cleaning seta; note large digitate scale setules and many small knife-like scales; $\times 2430$. B. Third maxillipede epipod, Cronius tumidulus; $\times 32$. C. Typical barbed epipod seta, from B; $\times 4860$. D. Enlarged barb from seta shown in C; $\times 2430$. E. Grooming chela (chela 2) of Thor manningi; leaders indicate tuft of grooming setae $(\mathrm{gs}) ; \times 178$. F. Magnification of grooming seta from $\mathrm{E}$; note digitate scale setules; $\times 3240$. 

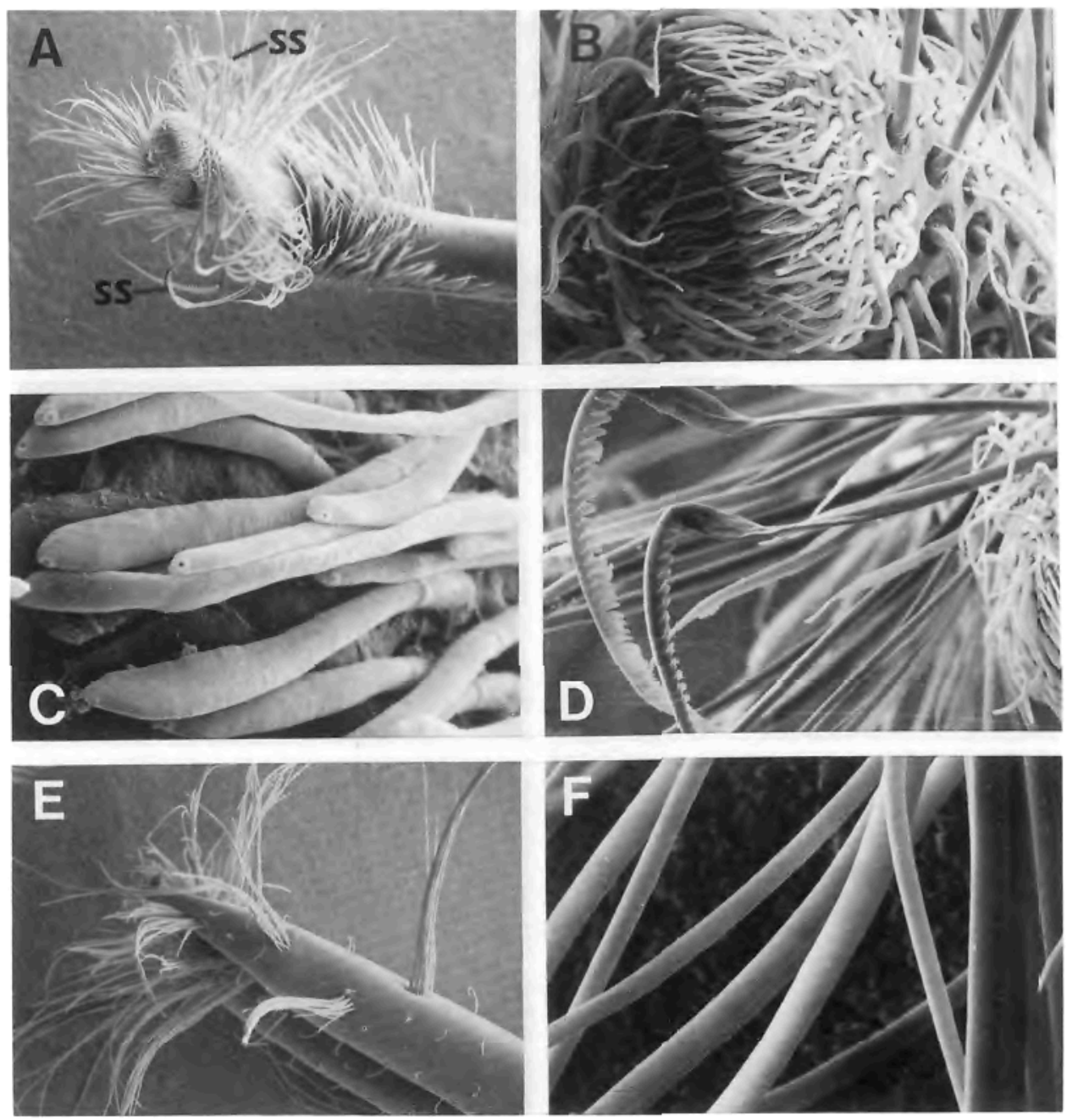

Figure 13. A. Distal end of chelate fifth pereiopod, an anomuran grooming appendage, from Petrolistines galathinus; ss - sickle setae; $\times 63$. B. Tips of chela, P.galathinus pereiopod $5 ; \times 437$. C. Enlargement of setae on tips of chela fingers from B; $\times 2920$. D. Magnification of two sickle setae (see A) of P.galathinus; $\times 292$. E. Fingers of chela 1, Stenopus hispidus; $\times 53$. F. Setae from tufts on chela 1 fingers of S.hispidus shown in E; $\times 972$. 

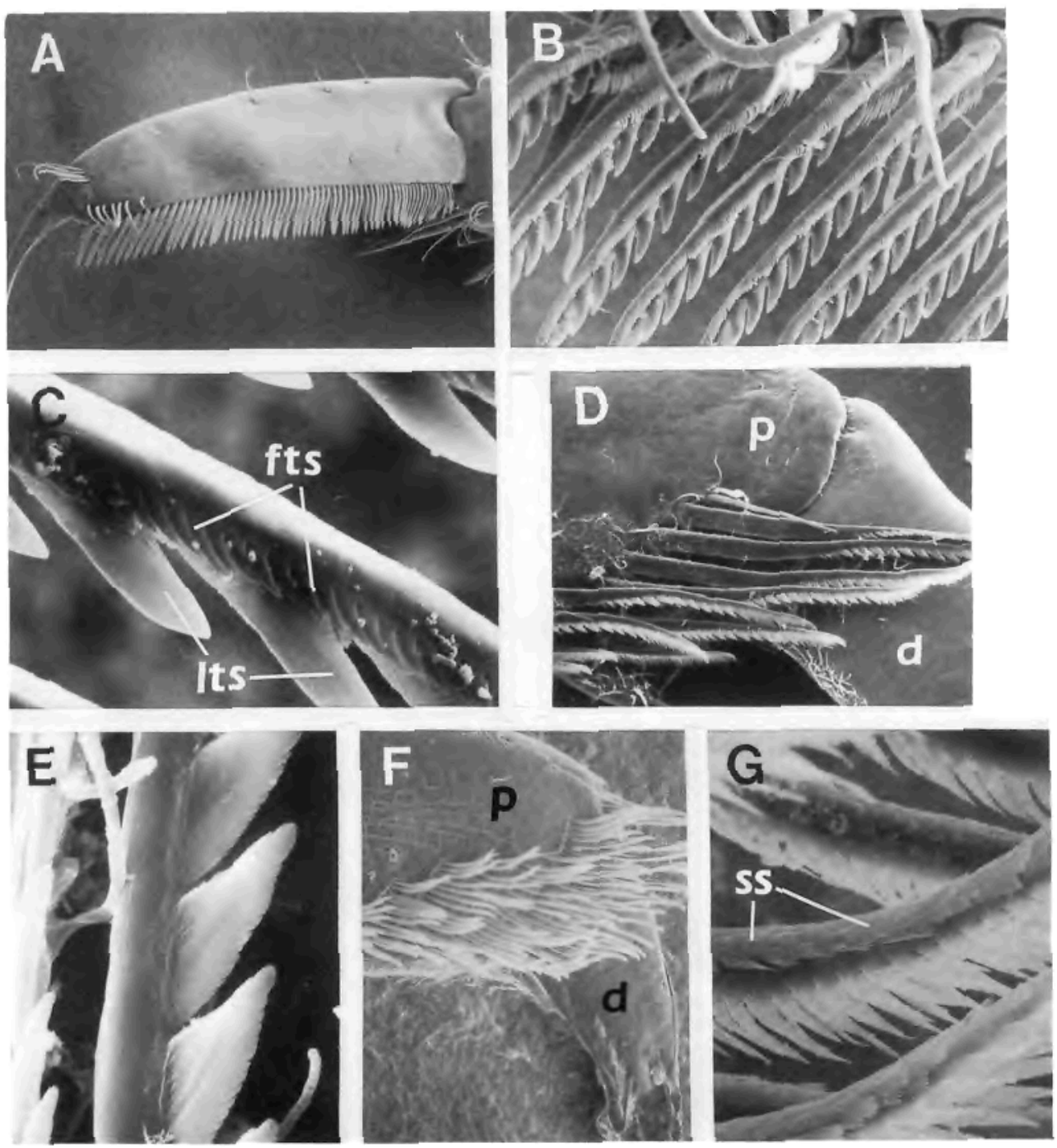

Figure 14. A. Dactylus with setal comb, pereiopod 5, Xiphocaris elongata; $\times 49$. B. Setae from dactylar comb shown in A; $\times 389$. C. Magnification of dactylar comb seta (A, B), showing row of large tooth setules (lts) and row of fine tooth setules $(\mathrm{fts}) ; \times 2106$. D. Propodal-dactylar joint, pereiopod 5, Palaemon ritteri, showing propodal grooming setae; $d$ - dactylus; $p$ - propodus; $\times 162$. E. Magnification of propodal grooming seta, Pritteri, from D; $\times 1620$. F. Propodal- dactylar joint, pereiopod 5, Betaeus macginitieae, showing rows of propodal grooming setae; d-dactylus; p - propodus; $\times 81$. G. Propodal grooming setae, B.mac ginitieae, from F; ss - scale setules; $\times 1336$. D-G from micrographs used in figures by Baucr (1976). 